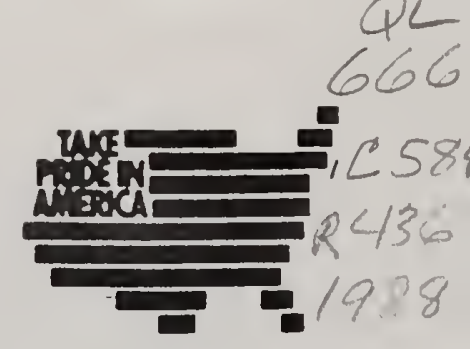

IN REPLY REFER TO: 6840 (CA-068)

MEMORANDUM

To:

District Manager, California Desert District, BLM

Regional Manager, Region 5, California Department of Fish and Game.

Fram: Area Manager, Barstow Resource Area, BLM

Subject: Transmittal of Report entitled "Recommendations for Management of the Desert Tortoise in the California Desert".

In December of 1986, you asked that I chair a workgroup whose purpose was to develop recommendations for definitive actions that might be taken to improve and protect desert tortoise population and habitat in the California Desert. Attached is a copy of the report generated by that workgroup.

The recommendations contained in this report were developed from a tortoise advocacy position. They were not integrated into a multipleuse scheme that recognized other legitimate land uses or social economic factors occurring throughout the California Desert. It was the position of the Workgroup that final decisions concerning tortoise management ought to be made in the public arena through other processes outside the scope of the Workgroup.

In order to implement the recommendations of the Workgroup, I suggest the following implementation strategy:

A. Implement the following recommendations by issuing policy and/or operational directives: $3,6,21,22,23,24,25,26,29$, $30,32,38,39,40,41,45$, and 47 .

B. Implement the following recommendations through an interagency workgroup; proposals thus generated would require the approval of the BLM District Manager and/or the Fish and Game Regional Manager: 4, 5, 7, 16, 17, 31, 34, 35, 36, 43, and 44.

C. Implement the following recommendations by amending the Desert Plan during 1988 and 1989: 1, 12, 13, 14, 19, and 20.

D. Implement the following recommendations by preparing habitat management plans during FY 1989: 8, 9, 10, 11, 15, 17, 27, 33, and 37.

E. Implement the following recommendations by funding studies and/or research: $2,17,18,28,42,46$.

$$
\begin{gathered}
\text { Take pride in your California Desert Conservation trea } \\
\text { of National Dreasure. }
\end{gathered}
$$


0

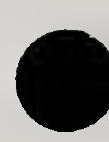

0 
2

The overall conclusion of the Workgroup was that the Bureau, the Department, and other state and local agencies must place a higher emphasis on managing the California Desert, and activities conducted thereon, in a manner that will be beneficial to sustaining healthy, viable tortoise populations. The involvement of all desert users, user groups, and residents will be critical to the success of such an effort.

Now that the task of the Workgroup is accomplished, I consider that the workgroup is no longer exists.

OldenSuivers

Attachment:

ii 
0

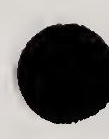

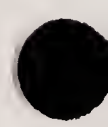




\title{
RECOMMENDATIONS FOR MANAGEMENT
}

\author{
of the Desert Tortoise \\ in the California Desert
}

\author{
SUBMITTED BY: \\ California Desert Tortoise Workgroup
}

\begin{abstract}
members:
Alden sievers. Chairman

Area Manager. Barstow Resource Area. Bureau of Land Management

Jeffrey B. Aardahl

Wildife Biologist. Ridgecrest

Resource Area. Bureau of Land Management

Kristin. H. Berry

Betty L. Burge

Larry D. Foreman

Tortoise specialist. Calif. Desert
District. Bureau of Land

Tortoise specialist. Calif. Desert
District. Bureau of Land Management Member. Board of Directors. Desert Tortoise Council

District Biologist. Calif. Desert District. Bureau of Land Management

George E. Moncsko

James A. St. Amant

President. Desert Tortoise Preserve Commit tee

Desert Area Fisheries supervisor. Region 5. Calif. Department of Fish and Game
\end{abstract}




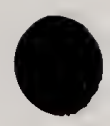

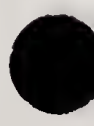

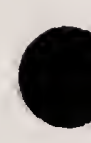


Transmittal letter. . . . . . . . . . . . . . . . i

Title Page... . . . . . . . . . . . . . . . iii

Table of Contents. . . . . . . . . . . . . . iv

List of Illustrations . . . . . . . . . . . . v v

I. INTRODUCTION . . . . . . . . . . . . . . . . . . . . 1

I I. STATUS OF THE DESERT TORTOISE . . . . . . . . . . . . 2

A. Population and Trend............. . . . . . . . 2

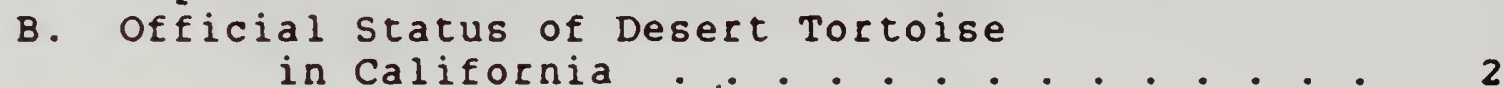

I I . MANAGEMENT FRAMEWORK • • . . . . . . . . . . . . . . 4

A. Major Laws which Affect the Tortoise. . . . . . 4

B. California Desert Conservation Area (CDCA) Plan 5

C. Land Ownership . . . . . . . . . . . . 6

IV. SUMMARY OF ISSUES . . . . . . . . . . . . . . . . . . 10

A. Population Issues . . . . . . . . . . . . . . 10

B. Habitat Issues... . . . . . . . . . . . . . 17

C. Interagency issues . . . . . . . . . . . . 23

V. MANAGEMENT GoAls AND OBJECTIVES . . . . . . . . . . . 25

VI. RECOMMENDED ACTIONS . . . . . . . . . . . . . . . . . . . 26

APPENDIX A. LITERATURE CITED . . . . . . . . . . . . . . . A-1

APPENDIX̣ B. SUMMARY OF RECOMMENDED ACTIONS . . . . . . . . B-l 
○

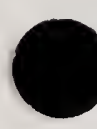

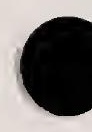


Illust. 1. Land ownership and administration in the California Desert Conservation Area.

Illust. 2. Map 8 from California Desert Conservation Area Plan showing eight areas designated as desert tortoise crucial habitats.

Illust. 3. List of issues with level of concern in the four major tortoise habitat areas (Western Mojave. Ivanpah-ShadowKelso. Fenner-Chemehuevi, and Chuckwalla.

Illust. 4. Map of California Desert Conservation Area showing category 1, 2, and 3 tortoise habitat areas.

Illust. 5. Map of California Desert Conservation Areas showing roadways recommended for lining with tortoise-proof fencing.

Illust. 6. Map of California Desert Conservation

Area showing areas recommended for prohibition of firearm discharge during the tortoise season.

Illust. 7. Map of California Desert Conservation

Area showing areas recommended for restriction of camping to designated campites.

Illust. 8. Map of California Desert Conservation Area showing acquisition priorities within four major habitat areas.

Illust. 9. Description of factors used to compute compensation rate. 
0

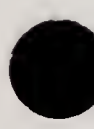

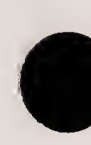


In December of 1986, the District Manager of the California Desert District. Bureau of Land Management (Bureau). and the Regional Manager of Region 5, California Department of $F$ ish and Game (Department). formed the California Desert Tortoise Workgroup with the charge of developing recommendations for definitive actions that might be taken to improve. protect and enhance desert tortoise populations and habitat. Five Bureau employees were assigned to the Workgroup - the Barstow Area Manager, the District Biologist, the District Tortoise specialist, the Ridgecrest Resource Area Wildlife Biologist, and the Barstow Resource Area Wildlife Biologist (who resigned from the Bureau prior to the first meeting of the workgroup). In addition. the Department, the Desert Tortoise Council, and the Desert Tortoise Preserve Committee were represented. The Barstow Area Manager was designated chairman of the Workgroup by the District Manager and Regional Manager.

During several meetings and field evaluations, the Workgroup 1) defined management goals, 2) identified major issues. 3) developed alternative methods for addressing the issues in the context of meeting the goals, 4) reviewed current management practices and their effects. and 5 ) selected recommended actions to improve management of the desert tortoise and its habitat.

This report documents the findings of the Workgroup. It is a majority report: consequently, there is not complete concurrence by Workgroup members on all recommendations or their areas of application. It has neither been reviewed by the organizations represented nor has it been approved by those officials of these organizations.

The Workgroup recommends that a number of Desert Plan amendments for the desert tortoise be initiated, that a series of habitat management plans for the desert tortoise be prepared, based on the recommendations contained in this report, and that the plan amendments and habitat management plans be presented to the public for review and comment. Specific desert user groups (including but not limited to miners, ranchers, and recreationists) should be involved in the preparation and review of the plan amendments and habitat management plans. 


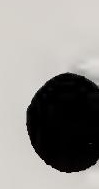

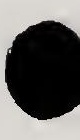

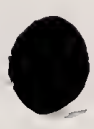


A. Population and Trend

In California, desert tortoise populations have experienced reductions in distribution and abundance since the late 1880's. In the mid-1970's, the Bureau established a series of study plots to determine population condition and rates of change. Since then. most plots have been surveyed two or more times, and trend data have been generated. Since most study plots are in areas with relatively little disturbance, populations may be lower overall than indicated by the study plots.

Trends vary substantially from one region of the California Desert to another. For example. most populations on study plots in the western Mojave Desert have experienced downward trends, ranging from losses of 10 to 60 percent in a six to seven year period. Significant changes have also occurred in the age distribution. with declines in relative numbers of juveniles. Overall, the Western Mojave is experiencing extensive and rapid population declines. populations are becoming increasingly fragmented, and habitat loss is significant.

In contrast, populations in the eastern Mojave and northeastern Colorado Desert show stability in some areas and low rates of declines in others. In southern Ivanpah Valley and near Goffs. study plot data show few significant changes: whereas populations on the Chemehuevi Valley and ward Valley study plots. appear to be declining slowly. Habitat losses in these areas are substantially lower than in the Western Mojave.

In the southern Colorado Desert, the once widespread population has become highly fragmented and restricted to a limited area. Two plots to measure trends were established between 1977 and 1980. One shows a significant decline while the other appears stable.

B. Official status of Desert Tortoise in California

The desert tortoise was designated a sensitive species in California in 1979 by the Bureau's state Director who is authorized to designate species on public lands as "sensitive" after consultation with the Department. The purpose of the designation is to provide increased management attention to prevent population and habitat declines which might result in Federal or state listing as endangered or threatened. 
○ 
The designation raises the level of concern for desert tortoise in the environmental process. No particular habitat or population management action is required or pronibited by the sensitive species designation.

In 1981 the U. S. Fish and Wildlife service (Service) contracted with the Desert Tortoise Council to analyze and report on the status of the desert tortoise throughout its range (California. Nevada. Arizona, and Utah). On the basis of the resulting report (Berry 1984), the Defenders of wildlife. Natural Resources Defense Council, and Environmental Defense Fund petitioned the service in 1984 to 1 ist the tortoise as an endangered species. In response to this petition. the service published a notice of review of the status of the tortoise. Based on the status report and other materials submitted in the review, the service made a finding that "the listing of the tortoise is warranted, but precluded by other pending proposals of higher priority." The tortoise is designated by the service as a category 2 candidate for Federal listing. Additional data is being gathered. and an annual evaluation is published by the service.

The desert tortoise is the official California state reptile and is protected by special state legislation which prohibits taking or harming tortoises. In 1983. the Desert Tortoise Council petitioned the Department to list the desert tortoise as a threatened species. The petition was withdrawn pending the Federal review of status by the Service. In August 1987. the Desert Tortoise council resubmitted the petition. In November. the petition was accepted by the Fish and Game commission, and the tortoise has been officially proposed as a state-listed threatened species.

In the fall of 1986, the Bureau formed a Bureauwide Task Force to establish a framework for the management of desert tortoise and its habitat throughout its range and for the cooperation of Federal and state agencies for the benefit of tortoise management. The Task Force recommended that 1) an interagency desert tortoise oversight group and state technical coordinating committees be established. 2) data analysis and interpretation be standardized. 3 ) desert tortoise habitat be categorized. 4) tortoise management and research be funded, and 5) a public education program be developed. 
0

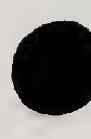

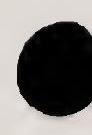


In general. the Department of Fish and Game is responsible for the management of animal populations, including the tortoise, on all public and private lands within the state of California. As a land management agency. the Bureau is primarily responsible for management of habitat. but only on public lands. In practice, the distinction between animal and habitat management is not rigid. Private landowners have a direct affect on habitat on their lands, but may not take, harm. or harrass tortoises.

A. Major Laws which Affect the Tortoise

1. Federal Land Policy and Management Act (FLPMA)

FLPMA (Public law 94-579) established the California Desert Conservation Area and directed the Bureau to prepare a plan for the management of the Conservation Area. FLPMA mandated the Bureau to manage the public lands under a concept of multiple-use and sustained yield. placing wildife resource management on an equal footing with the management of other resources.

2. Endangered Species Act

The Endangered species Act of 1973 (Public Law 97-304, as amended) charged all Federal agencies to seek the conservation of endangered and threatened species and to utilize their full authority to further the purposes of the Act. For terrestrial species, the U. S. Fish and Wildife service is responsible for designating species as threatened or endangered. The determinations are to be based solely on the best scientific and commercial data available. Critical habitat is usually designated for each species listed. The service also maintains a list of "candidate" plants and animals whose status is under review.

Once a species is listed as threatened or endangered. Federal agencies must consult with the Service on any action which may negatively affect the species. The service then renders a biological opinion on whether the proposed action will jeopardize the continued existence of the species. If 80 . alternative actions are recommended.

It is illegal to take, possess. harrass, sell, or transport any listed species. Individual animals 


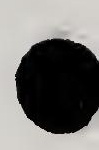

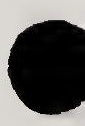

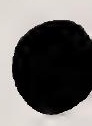


held in captivity on the date of official listing are not included in these prohibitions. Permits may be issued for taking of individual animals for scientific purposes or for the incidental taking of individuals of a listed species during the course of an otherwise legal activity.

3. California Endangered Species Act

In 1984. the State Legislature passed the California Endangered species Act. This law is patterned after the Federal Endangered species Act: it has similar provisions for consultations by state agencies. listing of species and designation of critical habitat. and regulating the taking of tortoises.

4. Sikes Act

The sikes Act (Public Law 93-452 and 95-420) authorizes the Bureau to develop and implement plans in cooperation with the state fish and game departments for the development and protection of wildife habitat. It authorizes the preparation of memoranda of understanding for the transfer of funds between agencies for the completion of projects. inventories. studies, and other programs.

5. Other Laws

There are a multitude of other laws which are significant to tortoise management by providing authority and mechanisms for regulating conflicting land uses. Among these are the Taylor Grazing Act, the Mineral Leasing Act, the Material sales Act, the Multiple surface Use Act, the Mining and Mineral Policy Act, and the Public Rangelands Improvement Act. In addition. the National Environmental Policy Act (NEPA). together with its state counterpart. the California Environmental Quality Act (CEQA). provide mechanisms for public disclosure and review of the effects of proposed projects and activities upon wildlife.

\section{B. California Desert Conservation Area (CDCA) Plan}

The "Desert Plan" signed in 1980 by the secretary of the Interior provides general management guidelines for the use and protection of resources in the California Desert. The Plan, as amended, provides for four major land use classes with various degrees 


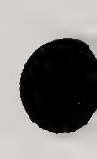

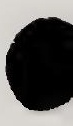

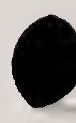


of resource protection and consumptive use allowed. The four classes are Controlled Use (C) (16 \& of public lands). Limited Use (L) (49q). Moderate Use (M) (28\%), and Intensive Use (I) (4\%). Unclassified lands total 3 percent of public lands. Guidelines restricting uses within the various classes were also established. See Illustration 1 for the acreages in each class.

The Wildife Element of the Desert Plan specified that habitat management plans were to be developed to prescribe management for tortoise habitat in five areas - Western Mojave. Fenner/Chemehuevi Valleys. Ivanpah Valley, Shadow Valley, and Chuckwalla Bench. Under Bureau policy. all such habitat management plans are to be prepared cooperatively with the Department under the authority of the sikes Act.

The Desert Plan (see Illust. 2) designated eight tortoise crucial habitat areas within the California Desert Conservation Area. It also called for the designation of highly crucial habitat within which sheep grazing is not allowed until 1) tortoise "emergence" has occurred in the spring and 2) 350 pounds of forage per acre is available. Within highly crucial habitat, sheep are to be restricted to one pass only through an area and specific bedding and watering sites are to be designated.

\section{Land ownership}

The CDCA encompasses about 25.5 million acres. Illustration 1 shows the approximate distribution of land ownership. The largest land manager is the Bureau which has management responsibility for 12.1 million acres (about 48 of the CDCA).

The Bureau manages lands under its jurisdiction based on the principles of multiple-use and sustained yield. The uses allowed, and their distribution, are prescribed by the Desert Plan. However. even within the guidelines of the Desert Plan, permitted actions must be approved generally through the Federal environmental assessment process prescribed by the National Environmental Policy Act (NEPA). Within the principles of multiple-use/sustained yield management, various uses and resource values may conflict in a given area.

About 24 percent ( 6.1 million acres) of the CDCA is privately owned. These lands are mostly vacant with little use or development. However. some lands, especially those in the western portion of the desert. 
•

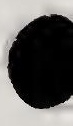

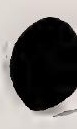


Illustration 1. Land ownership and administration in the California Desert Conservation Area.

Private

Federal

Bureau of Land Management

Class C (Controlled Use)

Class L (Limited Use)

Class $M$ (Moderate Use)

Class I (Intensive Use)

Unclassified

National Park Service

Death Valley National Monument

Joshua Tree National Monument

Military Reservations

Fort Irwin and Goldstone

Naval Weapons Center (China Lake)

Twenty-nine Palms Marine Base

Mojave B Range and Randsburg Wash

Chocolate Mountains Gunnery Range

Edwards Air Force Base

Carrizo Impact Area

Marine Corps Logistics Depots

George Air Force Base

other (including Bureau of Indian

Affairs. Bureau of Reclamation.

Fish and wildlife Service, and other small withdrawals)

State

Anza-Borrego state Park

other (including other small state parks. lands administered by the state Lands Commission. and Fish and Game refuges)

Local

City of Los Angeles (Dept. of Water and Power)

$\begin{array}{cc}6,096,000 & \underline{23.9} \\ (18.366 .000) & (72.0) \\ 12.120 .000 & \frac{47.5}{15.7)} \\ (1.900 .000) & (48.7) \\ (5.900 .000) & (48) \\ (3.400 .000) & (28.1) \\ (520.000) & (4.3) \\ (250.000) & (2.1) \\ 2.497 .000 & \underline{9.8} \\ (1.933 .000) & (7.6) \\ (564.000) & (2.2) \\ 2.998 .000 & \underline{11.6} \\ (635.000) & (2.5) \\ (610.000) & (2.4) \\ (568.000) & (2.2) \\ (559.000) & 2.2) \\ (457.000) & (1.8) \\ (127.000) & (0.5) \\ (31.000) & (0.1) \\ (6.000) & (\mathrm{T}) \\ (5.000) & (\mathrm{T}) \\ \underline{751.000} & \underline{2.9}\end{array}$

$(885,000)$

(3.5)

494,000

1.9

391,000

$\underline{1.5}$

$\underline{152,000 \quad 0.6}$

TOTAL

25.499 .000

100.0

1. $T=$ Trace 
$\bullet$

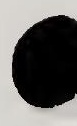

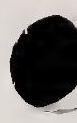




\title{
Illustration 2
}

Map 8 from California Desert

Conservation Area Plan showing eight

areas designated as desert tortoise crucial habitats.

\author{
CRUCIAL HABITAT $\begin{aligned} & 0000 \\ & 00000\end{aligned}$
}


0

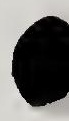

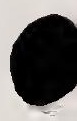


are being used for residential and commercial development. Agricultural development occupies large acreages in the Imperial and Coachella Valleys and smaller areas near the Los Angeles Basin. The largest private landholder is the santa Fe Pacific Realty Corporation which controls lands acquired in the 1800's during railroad construction. Railroad lands often are intermingled with Bureau lands in a checkerboard pattern.

Lands administered by the state Lands Commission total about 0.2 million acres: these lands are generally managed under multiple-use principles, with the emphasis placed on revenue generation. Other state and Federal agencies administer lands with a primary mission other than multiple-use. Among these are the National Park Service (Death Valley National Monument and Joshua Tree National Monument). the California Department of Parks and Recreation (AnzaBorrego Desert state Park. Mitchell Caverns state Park. Saddleback Buttes state Park. Red Rock Canyon State Park), and the Department of Defense (Edwards Air Force Base, George Air Force Base, China Lake Naval Weapons Center. Mojave $B$ Range. Fort Irwin Military Reservation. Twenty-nine Palms Air/Ground Combat Training Center. Chocolate Mountains Aerial Gunnery Range, and Carrizo Impact Area). 


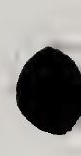

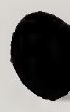

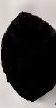


IV. SUMMARY OF ISSUES

Impacts have been identified which are adversely affecting the viability and stability of tortoise populations in the California Desert. These issues represent the collective perceptions of the members of the Workgroup.

In general. these issues can be divided into three basic categories: those affecting tortoise populations directly. those affecting primarily tortoise habitat, and those involving agency coordination. Collectively, these issues represent the negative factors which, if not properly addressed, will result in further declines and perhaps the eventual extinction of the desert tortoise in the California Desert.

A brief description of each issue follows. Illustration 3 lists the issues and identifies, in a general way. the relative importance of each issue for the four major habitat areas.

A. Population Issues

1. Illegal collecting

Collecting of tortoises for pets, food, scientific purposes. and commercial sale is reducing the number of tortoises in their natural habitat. Although the sale and purchase of tortoises was legally banned in 1939. problems with collecting continue (St. Amant 1984). In 1961, 1972, and 1973. the Fish and Game Codes were strengthened to prohibit collecting of wild tortoises. Although the tortoise populations in closest proximity to urban areas face the most severe problems. the actual numbers of tortoises lost through collecting and the specific locations from which they are being collected are not known.

2. Permits for Possession of Captive Tortoises

Permits to possess tortoises are being indiscriminantly issued. thus indirectly encouraging the illegal collecting of tortoises. Technically. tortoises acquired prior to 1961 can be legally possessed only if the owner obtains a permit from the Department. as prescribed in Fish and Game Codes 674, 5001, and 5002 (St. Amant 1984). Since 1961. tortoises cannot be taken legally form the wild. In practice. the Department will issue a permit to almost anyone who applies. Although the legislation has been in effect since 1961. only a small percentage of people with captive 
.

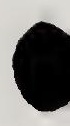


Il lustration 3. List of issues with level of concern in the four major tortoise habitat areas (Western Mojave. Ivanpan-shadow-Kelso. Fenner-Chemehuevi. and chuckwalla). The level of concern is indicated as high (H), mediura (M). low ( $($ ) , rangewide $(+)$, or not applicable in the area ( - ).

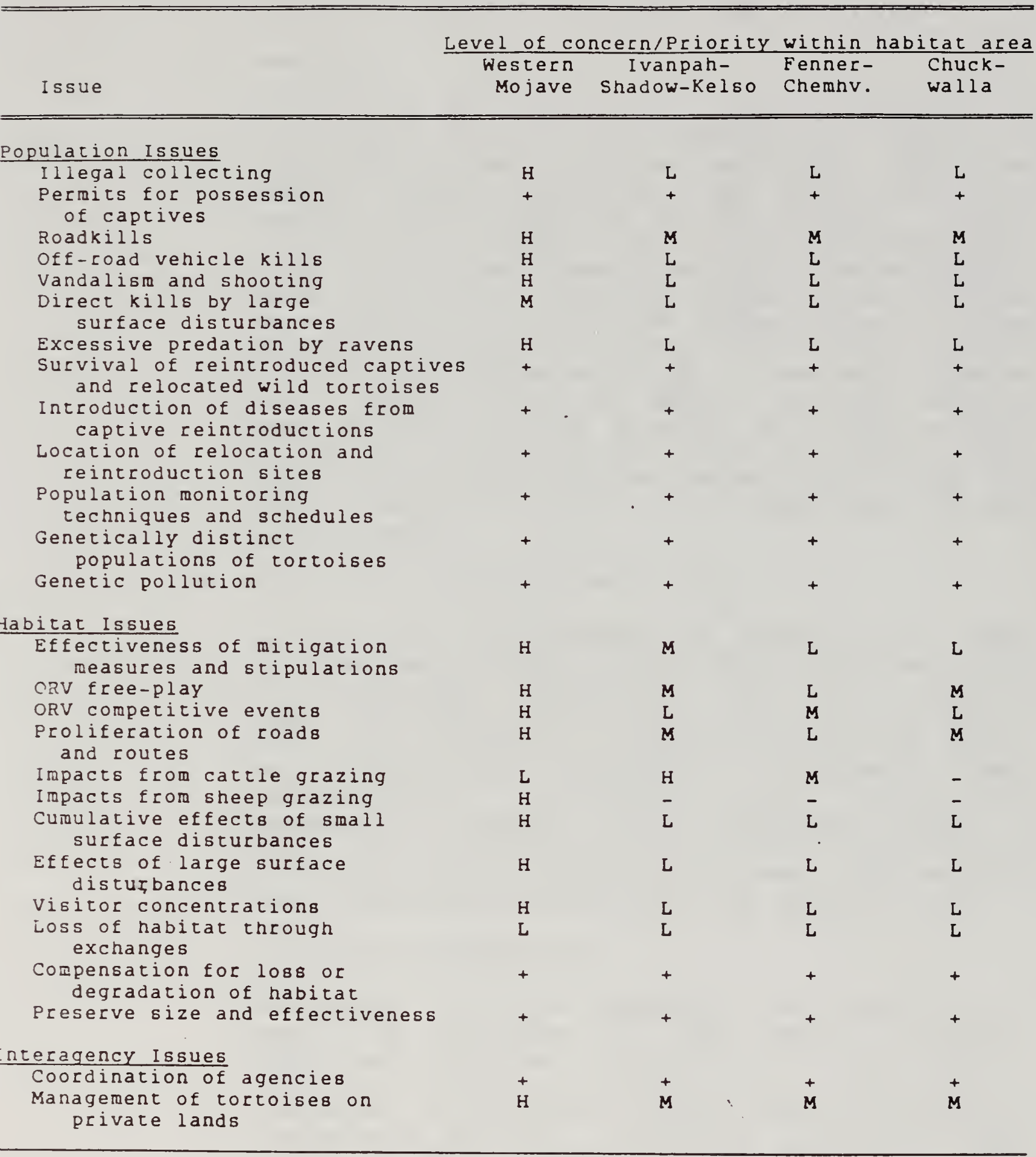


•

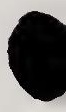

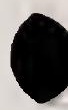


tortoises are aware of the regulations. The Department generally does not confiscate captive tortoises and seldom issues citations. Thus. illegal collecting is indirectly encouraged.

\section{Roadkilis}

The killing of tortoises by vehicles on paved and dirt roads and trails is reducing the numbers of tortoises in their natural habitats. Nicholson (1978a, 1978b) demonstrated that paved roads with regular vehicle use can deplete tortoise populations up to a distance of one mile from the road, with the greatest impact in the first half-mile. Berry and Turner (1984) confirmed these findings in an analysis of tortoise distribution on three Bureau study plots adjacent to roads. Similar losses can be expected on dirt roads with regular use. Surveys from the Desert Tortoise Natural Area in 1979 and 1985 revealed that tortoises are killed even with very low levels of vehicle traffic on dirt roads in the fenced portions of the Desert Tortoise Natural Area (Berry and shields et al. 1986 ).

4. Off-highway Vehicle (OHV) Kills

Vehicle travel off-highway is resulting in deaths to tortoises on the surface and in burrows. Berry and Nicholson (1984a:3-31 to 3-33) reported observing tortoises directly killed or injured by ORV's and indirectly killed and injured by crushing injuries and depression fractures probably incurred while in burrows. Bury (1978, 1986 manuscript) reported that tortoises living in areas with heavy vehicle use show indications of poor health and significantly lower body weights than tortoises in areas with low levels of use.

5. Vandalism and shooting

Vandalism, including shooting, is reducing the number of tortoises in their natural habitat. Berry and Nicholson (1984b:3-11 to 3-12) summarized the literature on vandalism and shooting of tortoises in California using published material dating back to 1939. The issue is over 50 years old. and events are not rare or infrequent. Many reports are available on deliberate killing with vehicles and firearms. Other types of vandalism include beheading. overturning. and severing in half with blunt instruments. 
Berry (1986b) analyzed data from 11 permanent study plots and reported that 14.3 percent of carcasses showed evidence of gunshot. Study plots in the western Mojave Desert showed the highest incidence of gunshot. In that area, the lowest frequency was on the Kramer Hills plot (14.68). and the highest was on the Fremont Valley plot (28.98). In contrast. plots in the eastern Mojave and Colorado deserts showed frequencies of 0 to 3.1 percent. Data from the Desert Tortoise Natural Area indicate that the incidence of gunshot is as high in the interior of the area as at the interpretive center and outside the fence (Berry and shields et al. 1986). The higher rates of gunshot deaths in the Western Mojave probably are attributable to higher numbers of human visitors. greater vehicular access, and closer proximity to urban centers.

\section{Visitor Concentrations}

Visitor concentrations typically involve use of vehicles and increase tortoise mortality through habitat loss. crushing. collection, shooting, and vandalism. For example, despite the exclusion of vehicles. tortoise populations have declined significantly at the Desert Tortoise Natural Area interpretive center. presumably due to collection and vandalism.

7. Direct Losses from Large Surface Disturbances

Large surface disturbances are causing direct losses of tortoises both on and below the ground surface. Direct losses generally occur when there is a rapid encroachment of a surface disturbing activity into habitat supporting tortoises. Examples are land clearing. leveling. and vegetation removal using earth-moving equipment such as bulldozers and graders and land excavations for exposing and removing mineral materials such as fill dirt, sand, and gravel.

8. Excessive Predation by Ravens

Excessive predation of tortoises by ravens is reducing the number of tortoises in their natural habitat. In 1980 and 1981. Campbell found that ravens were killing juvenile tortoises at the Desert Tortoise Natural Area and were leaving the remains at wooden posts along the perimeter fence (Campbell 1983). Since that time. Berry (1985) evaluated avian predation in California desert 
•

.

. 
tortoise populations and found that raven predation is more common and at higher levels in the western Mojave Desert than elsewhere. Data gathered in 1986 and 1987 at permanent study plots indicate that raven predation levels have grown considerably since the late 1970's. For example. at the Kramer Hills plot in 1987. shells of 156 juveniles were found underneath a raven nest and perch. Excessive raven predation has resulted in significant shifts in age-class composition at the Natural Area and other sites in the western Mojave Desert (Berry and Shields et al 1986).

In the western Mojave Desert, raven populations have grown substantially since the 1940 's and 1950's, according to Eugene Cardiff. Curator of Natural History. San Bernardino County Museum. In the eastern Mojave Desert. ravens were rare between the 1920's and 1940's but have increased substantially (Berry 1985). Increases are suspected to be due to human influences - increases in food supplies (e.g.. garbage dumps, agricultural developments, and roadkills) and perches and roosts (e.g.. telephone poles. transmission lines, and cultivated trees).

9. Survival of Reintroduced Captive and Relocated wild Tortoises

Reintroduced and relocated tortoises have a low survival rate. Berry and Nicholson (1984b) reviewed reports on survival of reintroduced. captives in programs authorized by the Department. Between 1971 and 1980. over 200 captives were part of official rehabilitation and/or reintroduction programs. Overall. survival rates were low. By 1980. the Department had declared a moratorium on captive reintroductions because of concerns about poor survival. potential contamination of genetic strains. introduction of diseases. disturbance of social systems of recipient populations, and exceeding the habitat carrying capacity of recipient populations.

Berry (1986a) sumarized relocation efforts in wild tortoises. Some die, some settle at the release site, and many travel distances of several miles. Relocation efforts have suffered from many of the same problems associated with captive reintroductions.

In 1986. Glenn stewart and others initiated a 


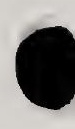

, 
relocation program near Kramer Junction in the Western Mojave as part of mitigation measures for development of a solar power plant. The project included following 16 relocated tortoises fitted with radio transmitters. In the first active season. about 25 percent have died or been poached. 12 percent have returned to their original homesites. 13 percent have moved away from the release site, and 50 percent have remained at the release site.

10. Introduction of Diseases from Captive Reintroductions

Reintroduced captive tortoises can spread diseases and parasites to wild tortoise populations. The literature on diseases of captive reptiles is extensive (e.g.. Cooper and Jackson 1981: Hoff et al. 1986). Captive tortoises contract numerous diseases and parasites rarely observed in the wild animals. Unfortunately. some owners of sick or injured captives return the animals to the desert, perhaps in the belief that a sick or injured animal will be able to recover in a "natural" setting. Sick tortoises have been discovered at the Desert Tortoise Natural Area between 1972 and 1986 (U. S. Bureau of Land Management 1986). Each year, many pet owners call government agencies for information on the location of the Natural Area so they can release their captives in a protected area.

Because captives with contagious diseases and parasites can contaminate wild populations. captive tortoises should not be reintroduced into the wild unless they are part of a well planned release program. Diseases and injuries can only be detected by a veterinarian experienced with tortoises.

11. Location of Relocation and Reintroduction sites

No sites have been identified for relocation of wild tortoises or reintroduction of captive tortoises. County. State, and Federal agencies frequently receive requests to relocate wild tortoises from areas experiencing surface disturbing activities. The Department has expressed an interest in reintroducing captive tortoises to the desert. To date. no appropriate release sites have been identified. Most sites from which tortoises have been recently eliminated have inadequate habitat due to severe surface 
.

. 
disturbances. Carrying capacity is unknown in most areas, but populations may be below carrying capacity in some places due to collecting. vandalism, vehicle kills, and raven predation.

12. Population Monitoring Techniques and Schedules

Although yielding highly significant data, the current monitoring system has had lapses and may not be representative of tortoise populations desertwide.

Between 1977 and 1979. survey techniques were developed to monitor status of populations in California (Berry 1984b). The standard survey technique consists of a 60-day spring survey on a site which is about one square mile in size. Tortoises are permanently marked, shell-skeletal remains are collected, and data are recorded on individual tortoises. Data analysis yields information on population density. distribution. mortality. size and age structure, and sex ratios.

Initially. 27 study sites were surveyed. Of the 27. 15 were selected for a permanent monitoring program. Originally. the Bureau planned to monitor each plot every three or four years. However, due to budget limitations, no plots were surveyed for two years in the early 1980's. As a result, some plots were not resurveyed for six or seven years. This extended interval can compromise the survey method as tortoise marks disappear and carcasses deteriorate.

Most of the 15 plots in the monitoring program are in relatively undisturbed locations, and most are in moderate to high density areas. Therefore. the plots should not be considered as representative of the entire desert, but, rather, as representative of the best conditions and populations. As some populations decline. it may be necessary to shift or add plots.

13. Maintenance of Genetically Distinct Populations

Because of genetic distinctions between tortoises from different regions, it is important to maintain the major population centers as viable units.

The geographic range of the desert tortoise extends from southeastern california through southern Nevada into extreme southwestern Utah and from there south through western Arizona to 


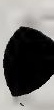

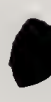


Sinaloa, Mexico (Stebbins 1985). However, desert tortoise populations are not one homogeneous genetic unit.

Recent work by Lamb (1986, 1987) and Weinstein and Berry ( 1987 ) indicate substantial differences in populations. Using mitochondrial DNA analysis. Lamb described three major genetic units separated by the colorado and Yaqui rivers. In addition. Lamb found that the unit north and west of the Colorado River (including California) has three distinct "clones". Weinstein and Berry (1987) have delineated three separate populations in the U.S. based on shell shape. The findings of Lamb and Weinstein/Berry correspond to some degree with each other and also with observed differences in habitat preference, seasonal activity patterns, and other behaviors. For example, tortoises west and north of the colorado River (including california) are generally found in valleys and bajadas and are uncommon in rocky areas. In contrast. tortoises in the sonoran Desert of Arizona occupy only rocky outcrops and steep. rocky slopes with large boulders.

14. Genetic Pollution

In the U. S.. usually tortoises have been taken captive and reintroduced without regard to their areas of origin. Releases have crossed state boundaries and major genetic units. Berry and Nicholson ( $1984 \mathrm{~b}$ : $3-8$ to 3-12) summarized some records of captive releases in california. Some releases were supervised by the Department, but probably many more releases occurred.

To preserve the genetic groups, it is essential that releases not mix either major genetic units or "clones". The major tortoise groups evolved in response to their environments and are probably uniquely adapted to live in a particular region. It is unknown whether individuals from different major units can hybridize or produce fertile, functional offspring with normal behaviors or survivorship.

B. Habitat issues

15. Effectiveness of Mitigation Measures and Stipulations

Mitigation measures. Which are project modifications designed to reduce an adverse impact, vary 
greatly in their effectiveness. Mitigations measures may or may not be sufficient to eliminate the adverse impact entirely. Mitigation measures are developed in the environmental assessment process and can become stipulations in land use authorizations or permits.

Most mitigations designed to reduce impact to the desert tortoise involve seasonal restrictions on access. slight changes in the project location to avoid direct loss or disturbance to tortoise burrows, and relocation of tortoises which would be killed by the project. The concept of compensation for direct or indirect habitat loss is not considered mitigation but rather a replacement for some of the loss.

Mitigation measures vary greatly in their effectiveness. For example, the requirement that vehicle speeds be reduced during project construction may still result in some tortoises being crushed by vehicles on roads.

The Bureau and most other agencies do not have adequate funding to either monitor the compliance with required stipulations or to assess the effectiveness of mitigation measures developed for various land use permits. In addition. casual land uses. such as general recreation involving motor venicles and operation of offhighway vehicles and some types of mining and exploration. do not require land use permits. In these cases. there is no opportunity for the direct application of mitigation measures. field compliance, or monitoring.

16. Off-road Vehicle Free-play

Vehicle free-play in tortoise habitat results in cunulative adverse impact to tortoise habitat. Impacts vary from minor habitat alteration and vehicle route proliferation to total denudation of extensive areas created by intensive vehicle play. parking. and camping. Concentrated vehicle play areas may eliminate all but the most hardy shrubs. such as creosotebush. Other impacts include soil compaction and erosion. Tortoises suffer from loss of forage, loss of vegetative cover, and loss of burrow sites and then become subject to increased mortality from crushing. collection, and vandalism. 
17. Off-road Venicle Competitive Events

Competitive events adversely impact tortoise habitat. They usually involve several hundred race participants and a significant number of spectators. In addition to street venicles. trailers, campers, and motorhomes are usually involved. The camping and race start and finish areas receive intensive vehicle use and become devoid of vegetation. Tortoises are eliminated from these areas entirely due to the loss of food. cover, and burrow sites. The adverse effects decrease with increasing distance from these concentration zones.

The effects of vehicle competitive events vary according to type of event, speed of vehicles. number of participants, etc. Some habitat is lost directly and is a function of route length and width. Routes usually widen with continued use. Events with mass starts at high speed result in large denuded start "cones" and greater course widening due to passing. spectators commonly participate in free-play, especially near camping and pitting areas.

18. Proliferation of Roads and Routes

Human access increases the incidence of tortoise mortality from collection, gunshot, and crushing by vehicles, and soil compaction results in loss of vegetation and increases in erosion. Vehicle roads and routes allow for human access into. tortoise habitat, especially in the western Mojave Desert where vehicle route density is high. Vehicle route proliferation has occurred in many areas and can result in a significant cumulative loss of habitat. Many routes are generated by casual cutting of corners and repeated crosscountry travel between routes.

19. Cattle Grazing

The evidence for impacts to tortoise habitat from cattle grazing is indirect and circumstantiai. Berry (1978) has suggested that cattle and sheep can eat and remove annual and perennial plants essential for tortoise food and cover. damage shrubs used for shelter. crush burrows and nests. and trample young tortoises. In addition to these immediate adverse effects, two long term effects of cattle grazing have been the conversion of some desert areas from grassland to 
shrubland and the replacement of perennial bunch grasses with introduced annual grasses, such as cheatgrass. Long term impacts to vegetation and soil are most pronounced along trails, at watering troughs and corrals, and at other concentration areas.

Cattle grazing has contributed to declines in some tortoise populations in Nevada, northern Arizona, and Utah (Dodd 1980. Mortimer 1984. Haley 1986). In the Beaver Dam slope population of Utah, malnutrition (Jarchow 1987) and trampling (Michael Coffeen and George Sheppard. pers. comm.) have been observed in all age classes. The impacts of cattle grazing are less known in California, perhaps because so few tortoise study plots are in areas grazed by cattle.

In Utah and Nevada, cattle grazing has been implicated as a cause in tortoise declines (Dodd 1980. Mortimer 1983. Haley 1986). Trampling of tortoises by cattle has been observed in Arizona and Utah (Michael Coffeen and George Sheppard. pers. comm.). Some live and dead tortoises also show depression fractures.

The degree and nature of impacts from cattle grazing is dependent on habitat, grazing history. seasons of use, stocking rates, and density of the tortoise population. In california, the cattle grazing in tortoise habitat is located mostly in the East Mojave.

\section{Sheep Grazing}

Like cattle, sheep can compete with tortoises for forage (especially key ephemeral forage). reduce protective cover. trample tortoises. collapse burrows, and crush nests. While cattle grazing is generally year-round, sheep grazing occurs in the spring. Which is the season of greatest tortoise activity.

Webb and stielstra (1979) found that a flock of sheep could consume 60 percent of the biomass of annuals with one pass. They also found that under heavy sheep grazing. perennial shrubs were reduced by 65 to 68 percent volume and by 16 to 20 percent cover. Nicholson and Humphreys (1981) documented impacts of sheep grazing on the kramer study plot. They found that 73 percent of the plot was grazed. About $\mathbf{4 . 4}$ percent of the plot received heavy impacts from bedding and water- 
ing. About 10 percent of tortoise burrows were damaged and 4 percent of burrows were destroyed. At least one juvenile was buried alive in its burrow. In 1987. Craig knowles reported that at least 10 juveniles were killed by trampling on the stoddard Valley study plot.

The Bureau has taken several actions to reduce the impacts of sheep grazing. The Desert Tortoise Natural Area has been closed to sheep grazing. Turnout in tortoise habitat must meet forage threshholds and in some areas must wait until tortoises have emerged from over-winter burrows. Other planned measures restricting bheep to one pass and requiring designated watering and bedding sites have not been implemented.

21. Cumulative Effects of Small surface Disturbances

Land use actions which disturb 5 to 10 acres or less cause significant indirect effects and cumulative impacts. even though when taken individually. such small disturbances appear trivial when compared with the distribution of the tortoise. For example, an exploratory drilling pad can lead to establishment of a new camping site or off-road vehicle staging area and result in increased habitat loss. collection of tortoises. vandalism, and vehicle kills. The presence of surface disturbances may contribute to further human activity within the same area. Uptain and Karl (1987: Figs. 7-9) provided substantial circumstantial evidence that the cumulative impacts of many small surface disturbances (dirt roads. air strip) at one site in the Western Mojave reduced tortoise populations over an area of 320 to 640 acres.

\section{Effects of Large Surface Disturbances}

Large surface disturbances (e.g.. power plants. agricultural developments, urbanization. commercial filming. off-road vehicle pitting and starting areas) cause longterm and often permanent loss of tortoise habitat. The loss in habitat results directly in reduced tortoise population. In addition. the activities often induce further surface disturbing activities with resulting habitat loss and population reduction. Large surface disturbances usually result in increased human activity resulting in vehicle kills. vandalism, and collecting of tortoises. 
23. Loss of Habitat through Land Exchange

Land exchanges are resulting in habitat loss and increased fragmentation of populations. In order to meet various other land use objectives (e.g.. blocking up wilderness areas or off-road vehicle open areas) or to accomodate a land use development (e.g.. agriculture, power plant siting), the Bureau undertakes land exchanges. Even where tortoise habitat is exchanged for tortoise habitat. there is an increased likelihood of development on the new private holdings.

24. Compensation for Loss or Degradation of Habitat

Projects proponents can reduce the overall effects of a project through compensation, which is the offsetting of the loss of habitat by enhancing management capability somewhere else. Compensation may. involve land acquisition. habitat improvement. or studies. In the last 10 years. Federal and state agencies in California have worked together with The Nature Conservancy to develop compensation packages to protect and improve management capability of species of special concern. The Department of Fish and Game, the California Energy Commission, the U. S. Fish and Wildife service. and The Nature Conservancy have played key roles.

The agencies involved have developed ratios for compensation for some species and some habitats in California (e.g.. deer. San Joaquin kit fox. Central Valley habitat). Typically, three factors are considered in developing compensation ratios - administrative costs of locating and purchasing habitat. the costs of the acquisition itself. and costs of rehabilitating or protecting the habitat. Other factors considered are the type of disturbance. time for recovery of the habitat. life history and behavioral requirements of the species. numbers of species of concern on the site. and other direct and indirect impacts. The California Energy Commission currently is requiring compensation for two projects in desert tortoise habitat (Luz solar plant and Argus cogeneration project) in the western Mojave Desert. Even with compensation, it must be recognized that there is a net loss in habitat.

25. Preserve Size and Effectiveness

As more and more species have had their distribu- 
tions restricted to protected refuges and parks. biologists working worldwide have recognized that these preserves are often too small to preserve the resources for which they were designed (Diamond 1975, 1976; Frankel and Soule 1981: Soule 1986: Soule and Wilcox 1980. Whitcomb et al. 1976). Key problems are that (1) small reserves generally have fewer species and higher extinction rates than large preserves: (2) some animals require large areas to survive: (3) large preserves are better buffered against human activities and natural disasters: (4) large areas are essential to minimize pressures of predation. parasitism, and competition exerted by species from nearby disturbed areas: and (5) the ratio of perimeter to area is less with larger areas.

The basic questions for the tortoise are: (1) how many breeding males contribute to the gene pool in a given population. (2) how much land is required to protect a viable population into perpetuity given the existing and future levels of human use. ( 3 ) how many different natural areas are needed. (4) can tortoise requirements be combined with general ecosystem requirements to avoid a "zoo" situation?

\section{Interagency Issues}

\section{Coordination of Agencies}

Policies regarding tortoises are not consistent among the various agencies. Management of the tortoise could be enhanced significantly with increased cooperation and agreement on certain policies.

Several levels of government influence land use policy and, thereby, affect the well-being of the tortoise and its habitat in the california Desert. Major agencies at the Federal level are the Bureau of Land Management, the Fish and Wildife Service, the National Park Service, and the Department of Defense: on the state level. the major agencies involved are the Department of Fish and Game. the California Energy Commission. the Department of Transportation, the state Lands Commission, and the Department of Agriculture. Counties and cities control activities on private lands. 


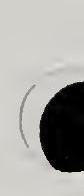

.

. 
27. Management of Tortoises on Private Lands

Because individual tortoises move around considerably and because a viable population requires an extensive area. the mixture of public and private lands offers a tremendous challenge to agencies charged with maintaining viable. stable populations of tortoises. Private land occupies from 4 percent (Ivanpah Habitat Area) to 46 percent (Fremont-stoddard Habitat Area) of tortoise habitat areas. In some areas. private sections may have as many as 200 individual landowners. Development on these private lands is generally controlled by city and county ordinances and general plans. 


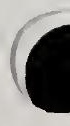

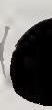

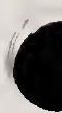


In recognition of its uniqueness in the desert fauna and its ecological and recreational importance, the desert tortoise is to be managed in a manner which will preserve it for the enjoyment of future generations and maintain it as an important ecological entity in the california Desert. Long-range goals for the management of the desert tortoise, in a non-heirarchial order, are to:

A. Maintain stable. viable tortoise populations within designated Category 1 and Category 2 habitats in the species existing natural range in the California Desert.

B. Minimize the impacts to tortoises in Category 3 habitat through humane and low-level mitigation requirements.

C. Eliminate non-natural mortality.

D. Minimize $10 s s$ and deterioration of Category 1 and Category 2 habitat.

E. Consolidate Category 1 and Category 2 habitats through acquisition program and through compensation for losses in Category 1. 2, and 3 habitats.

F. Maintain and increase populations through reintroduction of captives and relocation of wild tortoises.

G. Establish interagency coordination and commitment necessary to meet overall management goal.

H. Develop and implement a monitoring program to determine progress toward the defined overall management goal.

Section VI immediately following describes in detail actions recommended by the Workgroup to meet the above goals. A summary of the recommended actions may be found in Appendix $B$. 
MANAGEMENT GOAL A. MAINTAIN STABLE, VIABLE TORTOISE POPULATIONS WITHIN DESIGNATED CATEGORY I AND CATEGORY 2 HABITATS IN THE SPECIES' EXISTING NATURAL RANGE IN THE CALIFORNIA DESERT.

Recommendation 1: Define Category 1, 2, and 3 habitat areas as shown on Illustration 4. Discontinue use of concepts of crucial and highly crucial habitat.

Implementation: An amendment to the CDCA Plan should be proposed to designate three categories of habitat and to change provisions of the Desert Plan which reference crucial and highly crucial habitat. The four major areas of tortoise habitat should be known as Western Mojave. Ivanpah-Shadow-Kelso, Fenner-Chemehuevi, and Chuckwalla Habitat Areas. The proposed boundaries are approximate and should be confirmed. refined, or redefined in the public review process.

Discussion: Currently, eight areas are defined as tortoise crucial habitat on Map 8 in the CDCA Plan (Illust. 2). The Bureau's Tortoise Team report ("Management of Desert Tortoise Habitat") recommended adoption of a three-category habitat designation system to replace the designation of "crucial" habitat. The new categories are derived from current population and conflict information and were developed using the goals and criteria outlined below.

\begin{tabular}{|c|c|}
\hline & Category 1 \\
\hline Items & Habitat Areas \\
\hline $\begin{array}{l}\text { Category } \\
\text { Goals }\end{array}$ & $\begin{array}{l}\text { Maintain stable, viable } \\
\text { populations and protect } \\
\text { existing tortoise nabitat }\end{array}$ \\
\hline$\because$ & values; increase popula- \\
\hline Criterion & $\begin{array}{l}\text { Habitat Area essential } \\
\text { to maintenance of large, } \\
\text { viable populations. }\end{array}$ \\
\hline $\begin{array}{l}\text { Criterion } \\
2\end{array}$ & Conflict resolvable. \\
\hline Criterion & $\begin{array}{l}\text { Medium to high density } \\
\text { or low density contig- } \\
\text { uous with medium or } \\
\text { high density. }\end{array}$ \\
\hline$\underset{4}{\text { Criterion }}$ & $\begin{array}{l}\text { Increasing, stable, or } \\
\text { decreasing population. }\end{array}$ \\
\hline
\end{tabular}

\section{Category 2 Habitat Areas}

Maintain stable, viable populations and halt further declines in tortoise habitat values.

Habitat area may be essential to maintenance of viable populations.

Most conflicts resolvable.

Medium to high density or low density contiguous with medium or nigh density.

Stable or decreasing population.

\author{
Category 3 \\ Habitat Areas
}

Limit tortoise habitat and population declines to the extent possible by mitigating impacts.

Habitat Area not essential to maintenance of viable populations. Most conflicts not
resolvable.

Low to medium density not contiguous with medium or high density.

Stable or decreasing population. 


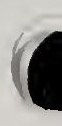

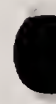




\section{Illustration 4}

Map of California Desert

Conservation Area showing

Category 1,2: and 3, Tortoise Habitat Areas.

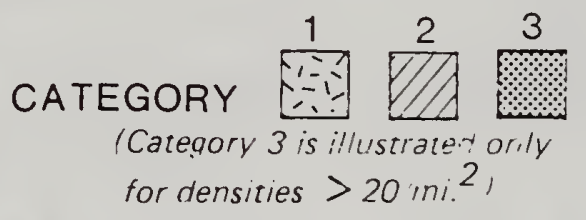

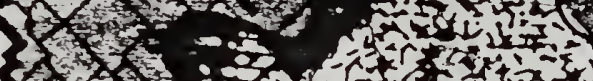

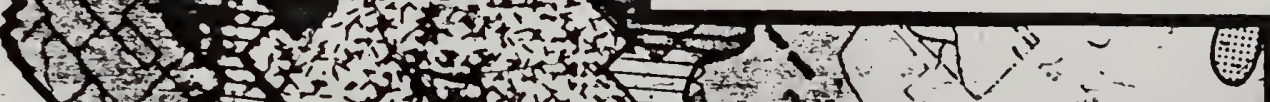
S. 3 on 0

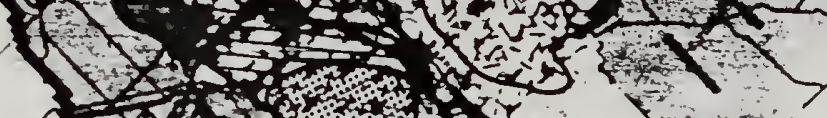

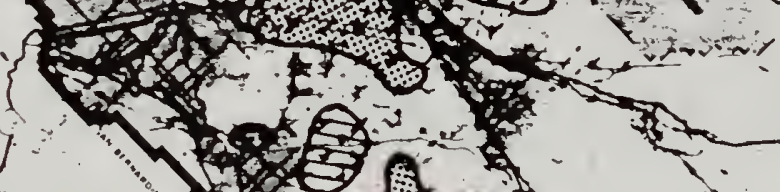
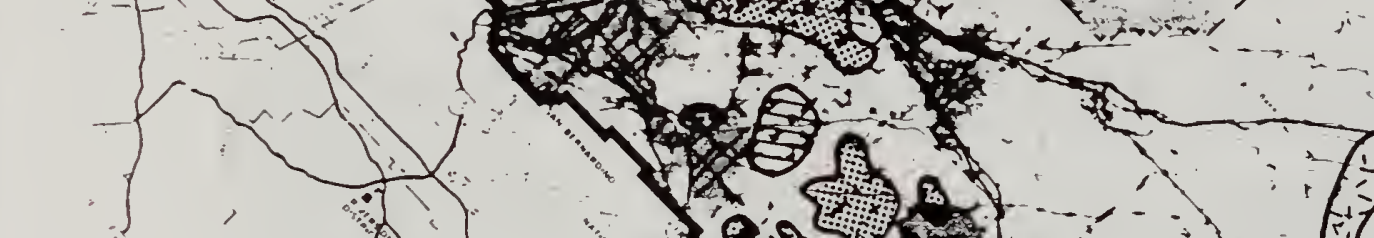

.

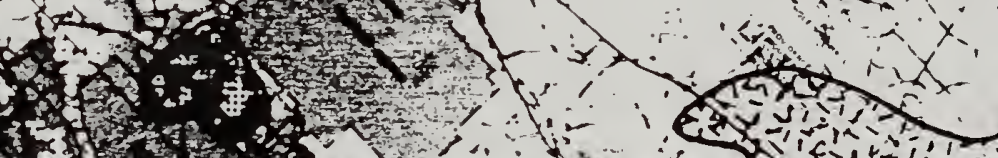

(a)

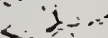

(ii=i=i,
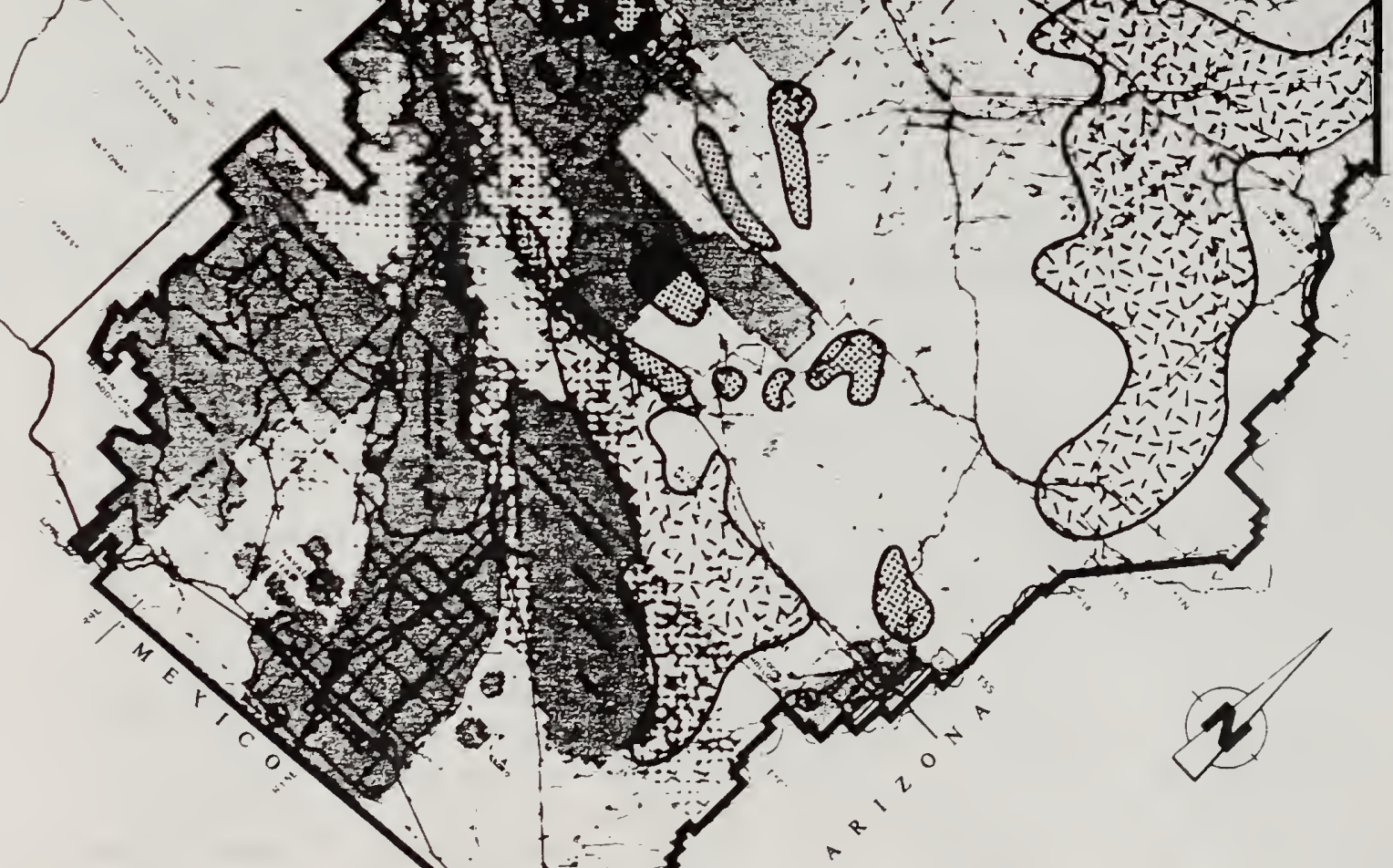

Lit
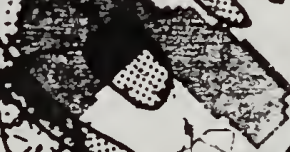

10.0

xat

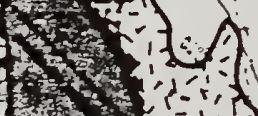

(1)

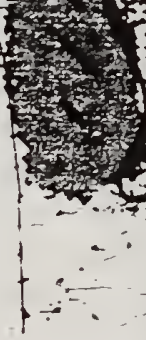


Recommendation 2: Determine the degree of population differences. separation. and isolation by examining morphological. genetic, and ecological data.

Implementation: Studies currently underway show some major and important differences. More work should be done. Discussion: In order to manage representative portions of each genetically distinct population. it is important to know the degree of differentiation that has taken place. Lamb (1986, 1987), Lamb et al. (1988), and Weinstein and Berry (1988) have shown that desert tortoise populations do occur in several major genetic and phenotypic units. Further research is necessary to define the differences and their relative importance.

MANAGEMENT GOAL B. MINIMIZE THE IMPACTS TO TORTOISES IN CATEGORY 3 HABITAT THROUGH HUMANE AND LOW-LEVEL MITIGATION REQU I REMENTS.

Recommendation 3: Apply humane and low-level mitigation measures to the maximum extent practical in Category 3 Habitat Areas.

Implementation: The direct and indirect effects of proposed projects and activities should be limited by the requirement for effective mitigation measures in all permits. licenses. grants, and other land use authorizations. Discussion: A wide range of measures have been used in the past to lessen the effects of a project. For example. restricting activities to the period when tortoises are in burcows can lessen direct effects. Reducing habitat disturbance is important in limiting the effects of a project. Other measures are discussed in more detail under objectives $C$ and $D$.

MANAGEMENT GOAL C. ELIMINATE NON-NATURAL MORTALITY.

Recommendation 4: Develop and institute an aggressive public education program to promote compliance with state and Federal laws and to reduce unnecessary mortality. The public education program should focus on six issues: (1) possession of tortoises (i.e.. permitting system). (2) illegal take. (3) prohibition on returning captives to the desert. (4) reduction in roadkills. (5) vandalism. and (6) protection of habitat.

Implementation: Target audiences should include the following: (l) the general public, with an emphasis on elementary students: (2) special interest groups (e.g.. off-highway vehicle users, shooters): (3) Bureau and Department employees. with an emphasis on managers. rangers and wardens. biologists, and others having con- 
tact with the public: and (4) planning agencies, with an emphasis on city and county planners.

Methods should include the following at a minimum:

(1) Preparation of education packets for distribution at Bureau and Department offices, county offices, and desert outposts, as well as rangers, wardens. and deputy sheriffs.

(2) Preparation of taped messages for an 800 telephone number. Messages should deal with poaching. legal and illegal possession. care of captives. release of captives, vandalism, road encounters. and sensitivity and values of the tortoise.

(3) Radio and television announcements, videos, slide programs, brochures, posters, decals, and stickers.

(4) Changes and updates of existing brochures and maps to include notices about status of tortoises. protective laws, vandalism, road encounters, and value of tortoises.

(5) Targeting specific user groups for special attention (e.g.. off-highway vehicle users, users of firearms).

Discussion: Unnatural sources of mortality and population loss can be markedly reduced through aggressive education programs. With proper education. many more people will voluntarily assist in efforts to protect the desert tortoise.

Recommendation 5: Confiscate all unpermitted tortoises. Implementation: A one-year registration and moratorium period should be established. After the registration period is over, the Department should seize all captives without permits and place them through approved adoption programs (see Recommendation 7) or experimental reintroduction programs (see Recommendation 35). Tortoises which can be shown to have been hatched in captivity should be issued a permit at any time.

Discussion: The collection of wild tortoises for pets is presumed to be a major cause of desertwide population declines during the past 50 years. The extent of the problem is difficult to assess, except by the large numbers currently held in captivity, especially in the urban areas of southern California. The Department's policy has been to issue a permit to anyone who requests one because of the difficulty of determining whether the tortoise was taken from the wild, was an escaped captive. or was hatched in captivity. In order to reduce the continued take of wild tortoises, all tortoises in possession without a permit should be assumed to be illegally collected. 
Recommendation 6: Promote return of recent captives to point of capture.

Implementation: Wild tortoises which are delivered to Bureau or Department offices soon after taking from the wild should be returned to the point of capture and released. Specific guidelines should be developed to cover such returns.

Discussion: Tortoises which have been living free and which can be returned to or near their former homes have a high likelihood of survival. They should not be carrying diseases from domestic animals, and they should not unduly disrupt other wild tortoises. Immediate return to the place of capture will give the best possible chance of survival in the wild for that individual.

Recommendation 7: Adopt captive tortoises to selected individuals through Turtle and Tortoise clubs.

Implementation: As established by criteria to be determined through consultations among various interested agencies and organizations. Turtle and Tortoise clubs should be commissioned by the Department to adopt captive tortoises to qualified individuals.

Discussion: Many captive tortoises are not appropriate candidates for release into the wild because of injuries and the potential for introducing disease (see Recommendation 35). The adoption of such captive tortoises will satisfy some of the demand for pet tortoises.

Recommendation 8: Reexamine vehicle route designations in Category 1 and 2 habitats to minimize routes in those habitats.

Implementation: A team of specialists from each Resource Area (including the area biologist and representatives of interest groups such as the Desert Tortoise Council and the Department of Fish and Game) should be assigned the task of reviewing routes in Category 1 and 2 habitats. Within these nabitats. the number of routes designated "open" in each square mile or township should be limited. The team recommendations should be submitted to the area manager for approval and processing through the annual route designation amendment process. New routes in Category 1 and 2 habitat should be authorized only when absolutely necessary.

Discussion: Routes result in direct impacts (mortality) as well as indirect impacts, such as proliferation of off-road vehicle play and illegal collecting. In the past. routes were not often designated with the purpose of reducing impacts to tortoises: a reexamination of routes may further identify closures that will be beneficial to the tortoise. 
Recommendation 9: Construct tortoise-proof fences along specified highways or dirt roads in Category 1 and 2 habitats and provide culvert underpasses.

Implementation: Illustration 5 shows highways and major roadways which should be considered for lining with tortoise-proof fencing. Following is a list of the roads:

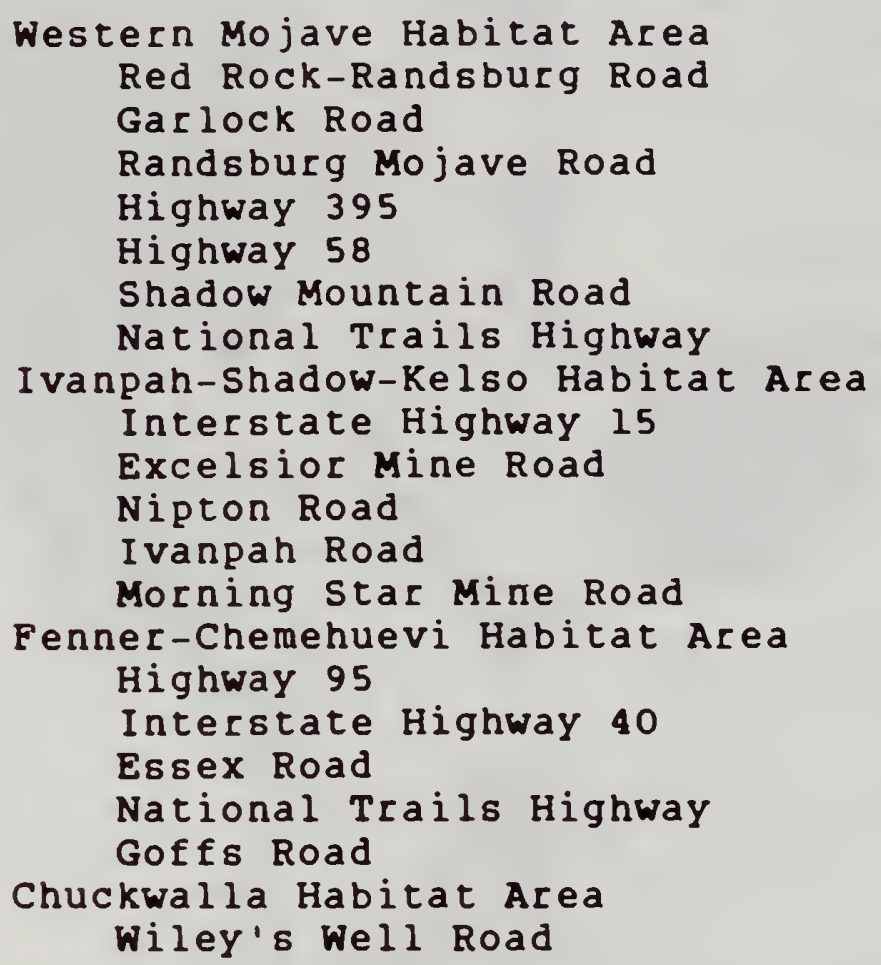

These highways carry heavy traffic and pass through prime tortoise habitat. Culverts should be placed at densities of at least 10 per mile of highway. Culverts and fences also should be constructed along new highways in category 1 and 2 habitats. Initial installations should be studied to determine use and effectiveness of design.

Discussion: Fusari (1981) has shown that tortoises will use culvert underpasses. Fencing can reduce roadkills and collecting on highways. The underpasses will allow some movement of tortoises under the highways and will reduce the highway's impact as a genetic barrier.

Recommendation 10: Construct tortoise-proof fencing along canals and aqueducts in Category 1 and 2 habitats. Implementation: Canals and aqueducts which pose a potential drowning problem for tortoises should be identified. Fencing should be considered on all such canals and aqueducts. Crossings at siphons should be maintained so that populations are not fragmented completely. Where siphons are widely spaced, additional wildlife crossing bridges should be considered.

Discussion: Canals and aqueducts are sources of direct 


\section{Illustration 5}

Map of California Desert

Conservation Area showing

roadways recommended for lining

with tortoise-proof fencing.

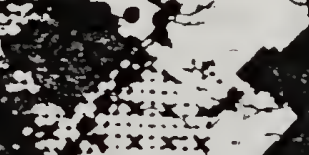

ax: $x: x$

ROADWAYS $\bullet \bullet \bullet \bullet$

(1)

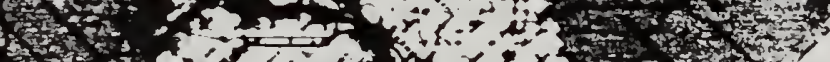

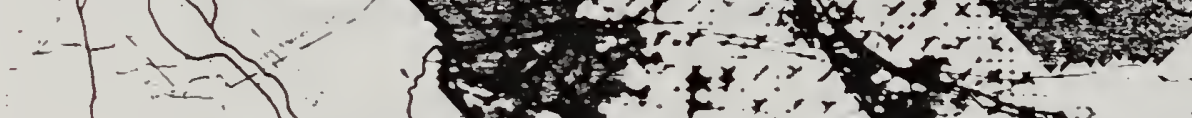
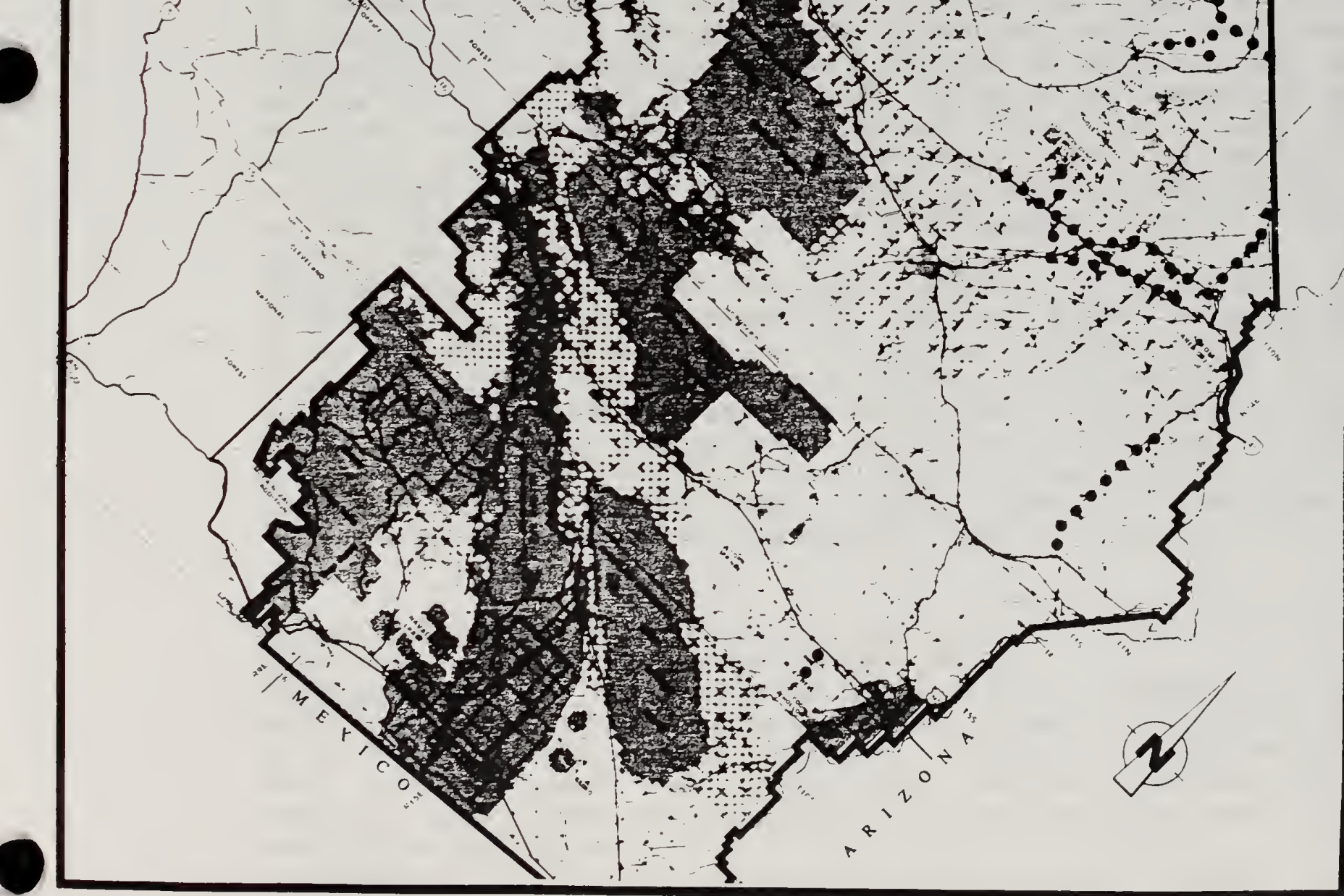
mortality and population fragmentation. Tortoises are non-swimmers and escape from canals and aqueducts is virtually impossible for them. Losses due to drowning could be a significant drain on nearby populations.

Recommendation 11. Fence, fill, or modify man-made pitfalls, such as mining shafts or exploration holes in Category 1 and 2 habitats.

Implementation: Open pits or shafts which can trap tortoises should be fenced to exclude tortoises. should have one or more sides sloped to allow for tortoises (and other wildiffe) to walk out, or should be filled. The option selected should be based on various factors including cost. the presence of bats or other wildife. and legal constraints.

Discussion: Tortoises are frequently found dead in pits and shafts. Elimination of pitfall mortality will increase tortoise survivorship.

Recommendation 12: Allow competitive or organized vehicle events within Category 1 or 2 habitats only within existing off-road vehicle open (free-play) areas or on race courses already identified in the Desert Plan.

Implementation: A Desert Plan amendment which confines competitive or organized events within category 1 and 2 habitats to off-road vehicle open areas or to Desert Plan approved courses should be submitted. High use or support areas (i.e. pits, start cones, camping, spectator parking or viewing areas) for ORV competitive events should also be excluded from category 1 and 2 habitats except in ORV open areas.

Discussion: Unlike use on other roads, participants in competitive events frequently depart from previously traveled roadways and often travel at speeds which preclude avoidance of tortoises. Competitive events also attract spectators and support personnel which spend time in ORV free-play. collecting. and other activities harmful to tortoise populations. Pits, start cones, and parking areas are extremely deleterious to tortoises because of the vegetation denudation and soil compaction.

Recommendation 13: Establish no new off-road vehicle open areas in Category 1 and 2 habitats.

Implementation: Any proposed Desert Plan amendments to establish new off-road vehicle open areas in category 1 or 2 habitats should be rejected. A Desert Plan amendment which states that there will be no new off-road vehicle open areas in Category 1 or 2 tortoise habitats should be submitted.

Discussion: It is imperative that large blocks of 
tortoise habitat be protected from denudation and soil compaction resulting from free-play.

Recommendation 14: Establish no new ORV open areas adjacent to category 1 or 2 habitats without a functional barrier.

Implementation: Proposals for new off-road vehicle areas should not be accepted for consideration unless a barrier is part of the proposal. Barriers include mountain ranges, other landforms. or freeways. Dirt or paved roads do not constitute barriers. Fences will constitute a barrier only if designed to keep tortoises in and vehicles out (e.g.. hogwire fence with hardware cloth at bot tom).

Discussion: There is considerable spill-over from offroad vehicle open areas onto adjacent lands. spill-over is expected to increase as open areas become crowded. denuded, and visually less attractive. Also, the natural movement of tortoises into. an open area will increase losses due to vehicle kills.

Recommendation 15: Increase enforcement of existing laws, regulations, and rules particular to protection of the desert tortoise within Category 1 and 2 habitats.

Implementation: The category 1 and 2 habitat areas should be analyzed to determine priority needs for enforcement of laws, regulations, and rules dealing with off-highway vehicle use, livestock grazing, and shooting. specific patrol and enforcement strategies should be developed for each Category 1 and 2 habitat.

Discussion: A number of laws, regulations, and rules which are of benefit to the tortoise already exist. priority for limited time of Bureau rangers. county deputy sheriffs, and Department wardens should be focused on tortoise protection during the spring and fall periods of above-ground activity. Existing laws, regulations. and rules need to be enforced as effectively as possible in order to reduce habitat loss and tortoise mortality.

Recommendation 16: Establish a shooting closure in the Western Mojave, as shown on Illustration 6. during the tortoise season.

Implementation: The counties of San Bernardino and Kern should be requested to issue regulations prohibiting the discharge of firearms from March 1 to October 15 within the Western Mojave. The Department should request the Commission to establish a jackrabbit hunting season from October 15 to March 1 in the same area. Enforcement should be by wardens. rangers, and deputy sheriffs.

Discussion: It has been shown by Bercy (1986b) that a 





high proportion of carcasses retrieved from the Western Mojave have been shot. Weapons used included rifles. shotguns, and handguns. The only legally obtained game during this period is rabbits and hares (year-round season) and mourning doves (season usually begins in early september). Most of the desert will still be open to discharge of firearms for lawful purposes (e.g.. jackrabbit hunting. target shooting).

In order to reduce the vandalism on tortoises by illegal shooting, a total restriction within the problem area is needed. Although licensed hunters are not believed to be the major problem, the permitting of licensed hunters to shoot during this period would make law enforcement difficult. Rangers and wardens need to be able to warn individuals carrying weapons of the restriction and need to be able to cite all shooters within the restricted zone without identifying the target.

Recommendation 17: Reduce raven predation on tortoises desertwide and continue to identify the scope of raven predation.

Implementation: Reductions in raven populations should be accomplished through cooperative efforts of the appropriate agencies (e.g.. California Department of Fish and Game, U. S. Fish and Wildlife Service, and Animal and Plant Health Inspection Service). Reductions should be through humane and cost-effective methods.

Human-related activities that contribute to increases in raven populations should be identified and. where possible. modified to discourage raven population growth. Examples include changes in management of garbage dumps. sanitary landfills. and sewage ponds. some structures may need modifying also to discourage perching, roosting, and nesting.

Raven populations should be monitored to determine population size and trend. concentration areas, and nesting areas. Monitoring efforts should emphasize areas where control efforts have been instituted.

Discussion: Since the late 1970's. ravens have had significant impacts on tortoise populations desertwide. Ravens eat juvenile tortoises. generally under the age of 7 years (Berry 1985). Growing raven populations and increasing levels of raven predation on juvenile tortoises have caused significant declines in recruitment (Berry and Nicholson et al 1986: Berry and Shields et al 1986: BLM tortoise files. 1987, 1988). In some tortoise populations, raven predation has caused recruitment to cease, and 15 years of juvenile and immature cohorts have been lost. 
Raven populations have increased greatly in the last few decades due to human activity. More specifically. raven food supplies have increased due to highway roadkills. dumps, agriculture, and urban development. Ravens are known to fly long distances (50 miles or more from nighttime roosts to daily foraging areas). They have no natural predators or enemies, except man. A reduction in raven predation on juvenile tortoises will allow a greater proportion of young tortoises to reach reproductive maturity and will help to increase and maintain stability in tortoise populations.

Recommendation 18: Determine whether guzzlers and livestock waters increase or concentrate canid populations and contribute to increased tortoise losses by predators. Implementation: Studies should be conducted to determine the use of artificial water sources by coyotes, kit foxes, and free-roaming dogs. If it is found that artificial water sources increase or concentrate canid populations, modifications to guzzler entrances should be made to limit access of canids within category 1 and 2 habitats. Livestock waters should be evaluated for most appropriate location and season of water availability.

Discussion: Coyotes, kit foxes, and dogs are known to eat eggs, young tortoises, and even adults. Kit fox predation on tortoise nests is high in some places (Turner and Berry 1985, 1986).

MANAGEMENT GOAL D. MINIMIZE LOSS AND DETERIORATION OF CATEGORY 1 AND 2 HABITAT.

Recommendation 19: Reduce the effects of cattle grazing on desert tortoise.

Implementation: Institute the following three measures. Full definition of the parameters needed will require cáreful analysis by a team of biologists, range conservationists. managers, and others.

a. Develop and submit an amendment to the Desert Plan to allocate forage and cover for desert tortoise on cattle allotments. Revise allotment management plans in tortoise habitat to include the tortoise forage and cover allocations.

b. Evaluate intensive use areas for cattle (e.g.. watering areas. loading areas. fence lines, salt lick and protein block sites). Develop mitigations to reduce the negative impacts of these intensive use areas. Incorporate these mitigation measures into the allotment management plans.

c. Develop a comprehensive monitoring program aimed at more precisely determining the impacts of cattle 
grazing on

assess the

tortoise

in the

California

Desert.

Re study plot first studied in 1980 and 1981 (Medica et al. 1982 :

Discussion: Desert tortoise populations in areas grazed by cattle in Nevada, Utah, and northern Arizona show population attributes indicative of declines. For example. the Beaver Dam slope population in Utah and northern Arizona populations are in serious trouble, possibly beyond recovery. Tortoise populations in parts of Piute valley. Nevada. also are experiencing high mortality rates and high rates of decline. Which have been attributed to cattle grazing. In California, the evidence is less clear. possibly because so few tortoise monitoring plots are in areas grazed by cattle. Action should be taken to avoid the grazing-induced declines observed in adjacent states.

Recommendation 20: Restrict sheep grazing in Category 1 and 2 habitats.

Implementation: An amendment to the Desert Plan should be submitted to eliminate sheep grazing in category 1 and 2 habitats: this should be the preferred alternative. An alternative amendment should be to allow sheep grazing only from April 1 to May 15 and to allocate ephemeral forage in Category 1 and 2 habitats only above 700 pounds/acre. Following Desert Plan amendment, the appropriate Grazing Decision Document should be produced, and allotment management plans should be revised.

Discussion: Affected allotments include cantil comon. Monolith Common. Superior Valley, Gravel Hills. Boron sheep. Buckhorn Canyon, and stoddard Mountain allotments in the Western Mojave Habitat Area and Ford Dry Lake allotment in the Chuckwalla Habitat Area. Sheep compete directly with tortoises for forage during the short. critical spring season when tortoises are above ground. Sheep forage intensively over the zone of passage and may reduce forage below requirements for tortoises present in that zone. This. together with other direct and indirect effects. is a contributing factor in the large declines in tortoise populations in the Western Mojave.

Recommendation 21: Restrict surface disturbing activities in Category 1 and 2 habitats to those which cannot be relocated elsewhere.

Implementation: Area Managers should attempt to relocate proposed surface disturbing activities to areas outside of Category 1 and 2 habitats. Where relocation is possible, permits for such projects within Category 1 and 2 habitats should be denied.

Discussion: Tortoise populations are limited by the 
habitat carrying capacity. Carrying capacity is determined by forage availability, burrow site availability. soil diggibility. etc. These factors are destroyed or negatively affected by surface disturbances. Activities which generally cannot be relocated include mining. geothermal energy development, and oil and gas development: most other types of activities are not location specific.

Recommendation 22: Minimize surface disturbance to soil and vegetation through mitigation measures in Category 1 and 2 habitats.

Implementation: For surface disturbing activities in Category 1 and 2 habitats which cannot be relocated (see Recommendation 21). disturbance to soil and vegetation should be minimized by the incorporation of effective mitigation measures. For surface disturbing activities in Category 3 habitat, similar mitigation measures should be applied (see Recommendation 3 ). The specific measures should be addressed in the environmental assessment for the proposed action, and the permit should be stipulated accordingly.

Discussion: Examples of existing mitigation measures include driving over or around vegetation rather than blading a road or work area and limiting the overall extent of roads or project work area.

Recommendation 23: Reduce the hazard of projects to tortoises through fencing within category 1 and 2 habitats.

Implementation: For projects where there is a danger of tortoises being killed by the activity itself (e.g.. run-over by vehicles) or of being trapped (e.g.. falling into a pit), a fence of woven wire with holes no greater than one inch should be placed around the hazard. Need for the fencing should be determined in the environmental assessment. If necessary. tortoises within the project area should be captured and relocated immediately outside of the project area. All costs should be borne by the project proponent. When the project is completed, the fence should be removed as a part of reclamation (see Recommendation 24).

Discussion: Although habitat will be lost at least temporarily, it is important to minimize direct mortality. especially for an animal which is long-lived and has a low reproductive capacity.

Recommendation 24: Require rehabilitation and/or restoration of vegetation in Category 1 and 2 habitats.

Implementation: For permitted surface disturbing activ- 
ities, project proponents should be required to restore the land to productivity by replacing topsoil. recontouring. reseeding with appropriate native annuals, and replanting native perennials (if determined feasible by the manager with botanical staff technical advice). All required restoration/revegetation projects should be monitored and evaluated for effectiveness. Monitoring should include vegetation transects and photo trend plots. Project proponents should be responsible for the costs of extensive vegetation monitoring: these requirements should be identified on the permit.

Discussion: The intent is to return habitat carrying capacity as quickly as possible to the original, undisturbed level. Annual plants are the primary foods for tortoises, and perennial plants are used for cover from sun, weather, and predators. Previous attempts at replanting perennials have met limited success. Some cacti and other plants can be replanted, but most require irrigation. which often is not feasible. Careful monitoring will show the success. of rehabilitation/restoration various techniques. As revegetation techniques are improved, the success of this measure will increase.

Recommendation 25: Require compensation for habitat degradation or loss in Category 1 and 2 habitats. Implementation: Compensation should be in the form of habitat enhancement, land acquisition, studies, or funds to be used for any of these. Compensation is normally considered to be off of the project site. The formula for determining compensation is identified in Recommendation 31 .

Discussion: The acquisition, enhancement, and protection of habitat assists in meeting the goal of maintaining stable, viable populations. Habitat enhancements include any permanent improvements, such as exclosures, fencing. reseeding. or signing. Not included are temporary measures, such as ranger patrols. Studies which reveal information pertinent to tortoise management or conflict resolution also work toward that goal. The amount of compensation reflects both direct loss of habitat and indirect losses due to the future effects of the project. The future effects might be direct, such as tortoise losses from vehicles associated with the project, or indirect. such as collection of tortoises by those using the project roadways.

Recommendation 26: Discourage facilities and activities which concentrate visitors in and adjacent to category 1 and 2 habitats.

Implementation: Area Managers should attempt to relocate proposed facilities and activities which would attract 
concentrated visitor use to areas outside of Category 1 and 2 habitats. Where relocation is possible. permits for such projects within Category 1 and 2 habitat should be denied.

Discussion: Concentrations of visitors can cause unusually high loss of tortoises due to collecting and vandalism. High losses in a small area can result in population declines and local extirpation. Activities which should be relocated include rallies and organized events. Facilities which can generally be relocated include campgrounds, movie sets, etc.

Recommendation 27: Allow camping only at designated campsites in Fremont Valley/fremont Peak/Cuddeback Dry Lake area.

Implementation: Areas proposed for restricted camping are shown on Illustration 7. The zone of restricted camping should be signed and shown on maps. Approved campsites should be identified within this restricted zone. These campsites should also be signed and shown on maps.

Discussion: In some areas, unrestricted camping can result in continued habitat destruction and/or loss of tortoises to collection or vandalism. Such locations include 1) areas where the presence of numerous vehicle tracks and trails encourages continued off-highway travel, or 2) areas where tortoise populations are known to be receiving unusually high collecting or vandalism.

Recommendation 28: Determine effectiveness of management of established tortoise preserves and. where necessary. modify management practices to ensure long-term maintenance of viable populations.

Implementation: The Desert Tortoise Natural Area, as an established preserve, should be monitored to ensure that tortoise populations remain stable. If declines occur. cáuses should be identified through appropriate studies. and corrective measures should be instituted. Where appropriate. additional preserves should be established to maintain viable, stable, core populations of high density.

Discussion: Preserves focus on conservation and management of target species or communities. Activities and uses in conflict with preserve goals must be reduced or eliminated.

Recommendation 29: Allow no land exchange which would reduce the amount of public ownership in Category 1 habitat.

Implementation: Land exchange proposals should be con- 



\section{IIIustration 7}

Map of California Desert

Conservation Area showing areas

recommended for restriction of

camping to designated campsites.

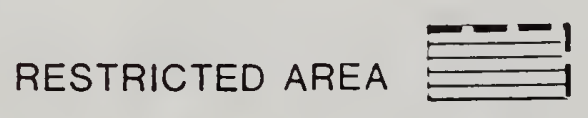



sidered only if involving Category l habitat for Category 1 habitat or if involving Category l habitat for other lands plus a compensation package for Category 1 which is at least as large as the lost lands. Exchanges should also consider the proposed use of the lost lands: compensation should be required to offset the effects (direct and indirect) of the proposed activity or project. See Recommendation 31 for details on compensation rates.

Discussion: The intent is to maintain the amount of lands under conservation management for the benefit of tortoises. It is imperative that the land base within Category 1 habitat is not diminished. In addition. projects with adverse impacts should not be facilitated by simple $1: 1$ exchanges: compensation for the adverse effects should result in at least an overall neutral effect.

Recommendation 30: Allow exchange or disposal of Category 2 or 3 habitats only if accompanied by an adequate compensation package involving acquisition of category 1 habitat.

Implementation: Land exchanges involving category 2 or 3 occupied tortoise habitat should be considered only if Category 1 habitat is acquired; additional compensation may also be required. See Recommendation 31 for details on compensation rates.

Discussion: Although it is not a goal to maintain the quantity of category 3 habitat in public ownership. the Category 3 habitat is to be used to the maximum extent possible to consolidate management of Category 1 and 2 habitats (see Management Goal E).

\section{MANAGEMENT GOAL E. CONSOLIDATE CATEGORY 1 AND 2 HABITATS THROUGH AN ACOUISITION PROGRAM AND THROUGH COMPENSATION} FOR LOSSES IN CATEGORY 1,2 , AND 3 HABITATS.

Recommendation 31: Apply the specified formula for compensation as required in Recommendations 25, 29, and 30 . Implementation: The formula described in the following paragraph should be applied where compensation is required. Compensation may be in the form of land, services, or funds. Services may include studies or habitat enhancement. Funds may be expended on land acquisition. studies, or habitat enhancement. No compensation funds should be expended on temporary measures, such as ranger patrols. The Bureau or other agencies, in consultation with the Department, should decide the amount of compensation, its. form (i.e.. services, funds, land), and, if land acquisition (currently the highest priority). where the land will be acquired. Land acquisitions should be 
in the closest Category 1 or 2 habitats; priorities for acquisition of habitat are shown in Illustration 8 . The project proponent should furnish funds to cover the acquisition or transfer the deeded lands directly. All lands acquired through compensation funds should come to the Bureau, the Department, or an appropriate conservation organization. Lands acquired by the Bureau through compensation or acquisition programs should be withdrawn from mineral entry and public land disposal laws.

Compensation formula. Compensation should be based on acres of land directly disturbed. The dollar value of the land disturbed or affected is to be considered only where habitat enhancement or services are to be paid for or supplied. The formula is designed to produce a factor which multiplies the number of acres of direct loss of habitat. The net multiplying factor should be computed using the formula below where codes and values are described in Illustration 9. This formula must be reviewed periodically for fairness and equity. Also. increases may be required if losses accumulate.

$$
\text { Multiplying Factor }=\frac{(L+S+A+G) X C}{T \times E}
$$

Discussion: Similar compensation packages have been used for many years. Compensation for game species (e.g.. deer) has often been calculated at a $3: 1$ ratio. Compensation packages for endangered species habitat have exceeded 10:1. The maximum multiplying factor is 14, but most projects will be only a fraction of that.

The formula is designed to offset direct loss of habitat and indirect and direct losses due to the future effects of the projects. The end result of compensation will be 1) acquisition of Category 1 and 2 habitats, and 2 ) enhanced management of tortoises. Although not a purpose of the compensation or a factor in the formula, the compensation package will function as a deterrent to conflicting activities in Category 1 and 2 habitats.

Recommendation 32: Increase acquisition of Category 1 and 2 habitats using funding sources in addition to compensation funds.

Implementation: Funds should be sought from appropriate state. Federal, and private sources to acquire additional lands within Category 1 and 2 habitats. Lands acquired for this purpose should be dedicated to tortoise management as the primary goal and. when acquired by the Bureau, should be withdrawn from mineral entry and public land disposal laws. Lands may be acquired by either the Department or the Bureau. The Bureau should encourage 


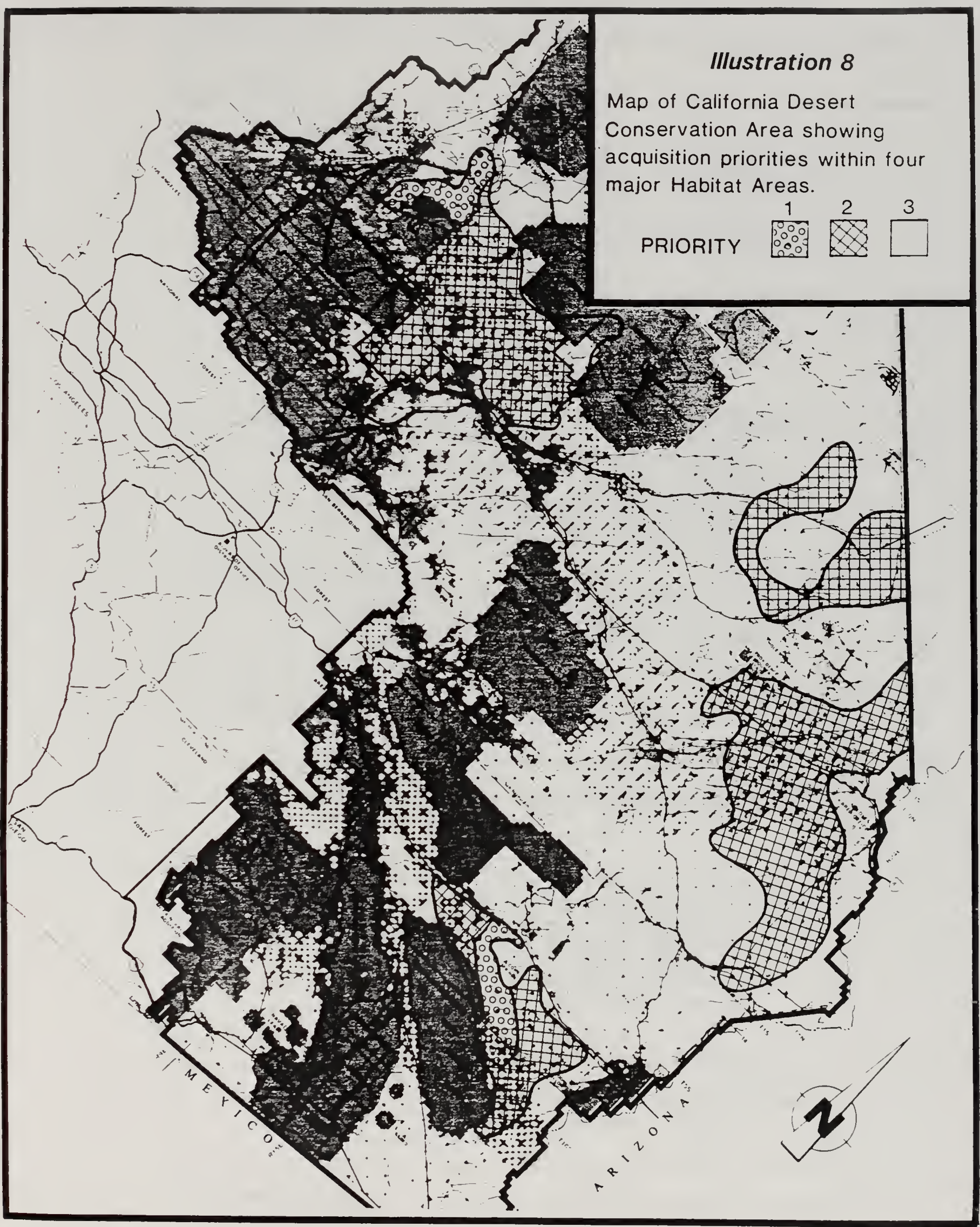



Illustration 9. Description of factors used to compure compensation rate.

Code Factor

Value

L Land disturbed or lost:

a) Tortoise habitat will be disturbed. lost to conservation management. or population density is expected to drop to o or nearly 0 in the near future.

b) Not as above - no compensation required.

S Sizel of project:

a) The project is less than 2 acres in size. 0.5

b) The project is between 2 and 160 acres 1 in size.

c) The project is greater than 160 acres 2 in size.

A Adjacent lands will receive additional impacts:
a) Adjacent lands will not be affected.
b) Adjacent or other lands will receive additional direct or indirect impacts which will reduce tortoise densities. Impacts will be assigned values of 1 (low). 2 (medium). or 3 (high).

G Growth inducing:

a) The project will have no growth or conflict inducing effects.

b) The project will have growth inducing or conflict effects.

C Category of habitat:

b) The above lands are in Category 1 tortoise habitat.

b) The above lands are in Category 2 tortoise habitat.

c The above lands are in Category 3 tortoise habitat.

T Term of effect:

a) The effects of the project are expected to be long term (longer than 10 years for habitat to have useable forage and cover).

b) The effects of the project are expected to be medium term ( 2 to 10 years).

c) The effects of the project are expected to be short term (less than 2 years).

E Existing disturbance on site:

a) There is little or no existing habitat 1 disturbance.

b) There is some existing habitat disturbance. 2

c) There is extensive existing habitat 3 disturbance.

1. "Size" refers to the actual area disturbed or to be lost to conservation management. 

other organizations (e.g. The Nature Conservancy, Desert Tortoise Preserve Committee. Desert Tortoise Council) to contribute lands. Illustration 8 shows the land acquisition priorities.

Discussion: Lands within the Desert Tortoise Natural Area have been acquired by several organizations. Such programs have been small in scope in the past but have a potential to increase as public concern for the tortoise grows. In order to manage lands for the protection and enhancement of tortoises. it is essential that development projects beyond the control of the Bureau or Department do not occur on intermingled private lands. Such projects often diminish management effectiveness and indirectly affect populations on adjacent lands. The most effective way to avoid this is to purchase the intermingled private lands.

Recommendation 33: Rehabilitate existing and acquired lands within Category 1 habitat using compensation funds. contributed funds, and state and Federal wildife program funds.

Implementation: Within category 1 habitat, projects should be undertaken to enhance habitat (e.g.. vegetation restoration. road rehabilitation. filling of pitfalls. removal of hazards) or increase management capability (e.g.. exclosures, fences, interpretive centers, signing). These actions should be undertaken as they are identified and as funding becomes available.

Discussion: These measures will aid in stabilizing or increasing tortoise populations by reducing conflicts. reducing mortality, or increasing carrying capacity.

MANAGEMENT GOAL F. MAINTAIN AND INCREASE POPULATIONS THROUGH REINTRODUCTION OF CAPTIVES AND RELOCATION OF WILD TORTOISES.

Recommendation 34: Conduct all relocation of wild tortoises under experimental controls until adequate information is available to ensure that tortoises can be effectively and humanely relocated. Relocation of wild tortoises should take precedence over reintroduction of captive tortoises (see Recommendations 35 ).

Implementation: Relocated wild tortoises should not be mixed into the same project with reintroduced captive tortoises. All wild tortoises to be relocated should be marked. and some should be radio-tagged for monitoring. The Department should supervise the relocation and provide personnel to evaluate the success by following marked individuals over both the short term and long term. All relocations of wild tortoises onto public 
lands must be within an area with an approved habitat management plan which specifically describes the relocation project. Bureau state Director approval is required for all relocations onto Public Lands, and Department approval is required for relocations anywere.

Discussion: Experimental relocations of wild tortoises may be part of a tortoise salvage project associated with a surface disturbing activity or may be individuals from a sharply declining (i.e.. threatened with local extirpation) population. Where associated with a project, the cost of evaluation of the relocation (i.e.. monitoring relocated individuals) should be borne by the project proponent. If conducted properly and at the proper season. survival rates for relocated tortoises are expected to be high since the tortoises are already capable of maintaining themselves in the wild.

Recommendation 35: Perform experimental reintroduction of captive tortoises. Relacation of wild tortoises (see Recommendation 34) will take precedence over reintroduction of captive tortoises.

Implementation: Reintroduced captive tortoises should not be mixed into the same project with relocated wild tortoises. All captive tortoises to be reintroduced into the wild should be examined (including blood testing) for indications of disease and parasites prior to release. Reintroductions should be made only into approved areas (see Recommendation 36). Reintroduced captive tortoises should be marked, and some should be radio-tagged for following. The Department should conduct the reintroductions and provide for personnel to evaluate the success by following marked individuals over the short term and long term. All reintroductions onto public lands must be within an area with an approved habitat management plan which specifically describes the proposed reintroduction project. State Director approval is required for releases onto Bureau lands, and Department approval is required for reintroductions anywhere.

Discussion: Such experiments will determine whether tortoises can be humanely and cost-effectively returned to the wild from captivity.

Recommendation 36: Identify relocation/ceintroduction areas of suitable habitat with no or very low (i.e.. below viable) tortoise population. with low land use conflicts, and within historic range.

Implementation: The Bureau, with assistance from the Department, should identify and conduct an evaluation of potential relocation/reintroduction areas. Prior to use of approved areas in a project, baseline vegetation/ habitat component surveys should be conducted to use in 


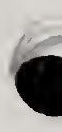

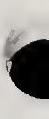

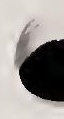


the evaluation of project success: these surveys should be conducted by the Bureau.

Discussion: Careful evaluation and designation of relocation/reintroduction areas will ensure that conflicting activities are not present or introduced. The intent is to determine relocation/reintroduction effectiveness and to establish a new permanent tortoise population or augment existing populations.

The following factors have been identified as important in the selection of a relocation/reintroduction area: (1) the habitat must be appropriate. (2) the carrying capacity must be sufficient to support the released animals. (3) the area must be large enough to withstand dispersal and homing movements. (4) impacts to the resident or host population should be minimal. and (5) the release area should receive long-term protection (Berry 1986a). Other factors which should be considered include: ( 1 ) wild tortoises should only be relocated within their genetic unit and (2) captive tortoises of unknown origin should be reintroduced only into an area with no host population and with sufficient geographic barriers to prevent dispersal to wild populations.

MANAGEMENT GOAL G. ESTABLISH INTERAGENCY COORDINATION AND COMMI TMENT NECESSARY TO MEET OVERALL MANAGEMENT GOAL.

Recommendation 37: Prepare a habitat management plan (HMP) for the desert tortoise in each of the four major tortoise habitat areas and a fifth HMP for the remaining Category 3 habitats.

Implementation: The recommendations made herein should constitute the basis for planned actions for the HMPs for management of the desert tortoise. The HMPs should be Bureau cooperative plans with the Department under the authority of the sikes Act. The HMPs should receive public review.

Discussion: An HMP is the appropriate mechanism for instituting these recommendations. It is Bureau policy that such HMPs be jointly developed with the state fish and game agency. Some of the recommendations made herein cannot be implemented through an HMP but will require amendment to the Desert Plan.

The California Desert Conservation Area Plan prescribes five HMPs for the desert tortoise - Western Mojave Crucial Habitat. Shadow Valley. Ivanpah Valley. FennerChemehuevi Valleys, and Chuckwalla Bench. The HMPs recommended here will fulfill the requirements for the five proposed in the Desert Plan. 


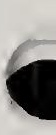

. 
Recommendation 38: Establish a Tortoise Coordinating Committee to facilitate interagency cooperation in maintaining viable tortoise populations in the California Desert.

Implementation: The Coordinating Committee should serve to exchange information, identify funding sources, promote cooperation, eliminate duplication of effort, share successes and failures, recommend actions to be taken by and priorities for agency managers. Participants should include representatives from the Bureau, the Department. the U. S. Fish and Wildife Service, and Desert Tortoise Council, and the counties of Kern, San Bernardino, and Riverside. Designated representatives should be technical rather than management oriented. Representatives from other agencies and interest groups should be invited to participate in and contribute to the Committee. Meetings should be held as needed to advise the Bureau District Manager and the Department Regional Manager on such items as:

Current status and trends in population.

Results and application of recent research and studies.

Status of research in progress.

Usefulness of proposed research.

Funding sources and needs.

Effectiveness of mitigation measures.

Application of compensation requirements.

Consistency among agencies.

specific management actions that should be instituted. and

Priorities for specific management actions.

subcommittees should be established to address specific items, as needed.

Recommendation 39: Encourage other agencies to implement the decisions resulting from the recommendations contained in this report on lands under their jurisdictions.

Implementation: Through various meetings and in review of environmental documents, the Bureau and the Department should encourage other agencies to use their authority in protecting and enhancing tortoise populations and habitat by applying consistent requirements, where appropriate. to their lands.

Discussion: Much of tortoise habitat is not controlled by the Bureau. In order to accomplish the overall goal of maintaining stable, viable populations, it will be essential that other lands be managed in a manner consistent with tortoise survival.

Recommendation 40: Establish in the Department of Fish and Game one or more biologist positions dedicated to 


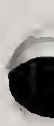

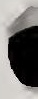


tortoise management.

Implementation: One or more biologists are needed to establish and maintain an expertise on tortoise biology and management within the Department. These biologists would fill curcent gaps within the Department on public education. tortoise permitting. supervision of relocations and reintroductions, and research on various tortoise population issues (e.g.. diseases, vandalism. illegal collecting. reintroduction. and transplantation). These biologists should work closely with the Bureau in developing and implementing habitat management plans and mitigation measures applied to projects.

Discussion: Implementation of the recommendations contained in this report requires an increase in focus on tortoises by the Department. The Bureau currently has one tortoise specialist dedicated to tortoise isssues.

Recommendation 41: Transfer tortoise management responsibility in the desert portion of kern county from Region 4 to Region 5.

Implementation: Region 5 should be responsible for issues and tasks relating to desert tortoise management. Tasks involved will include development and review of tortoise habitat management plans. review of environmental assessments. coordination with the Bureau and other agencies. review of research permits, etc.

Discussion: This transfer of responsiblity will aid in the consistency of tortoise management on a rangewide basis. The development of special tortoise expertise will be required only in one region.

MANAGEMENT GOAL H. DEVELOP AND IMPLEMENT A MONITORING PROGRAM TO DETERMINE PROGRESS TOWARD THE DEFINED OVERALL MANAGEMENT GOAL.

Recommendation 42: Survey four of fifteen permanent trend plots each year.

Implementation: Fifteen permanent trend plots have been identified for resurvey on a four-year cycle (Illust. 10). The surveys should be conducted under contract through the Bureau. Procedures are standardized and must be followed precisely to make comparisons possible. Analysis should be conducted annually and should evaluate changes in population attributes such as density. sex ratio. age structure, mortality rate, and reproductive rate. These trend plot data are vital in various research projects on measurements of tortoises and using shell remains.

Discussion: The fifteen plots were selected from 27 plots which have been surveyed. The fifteen were selected 


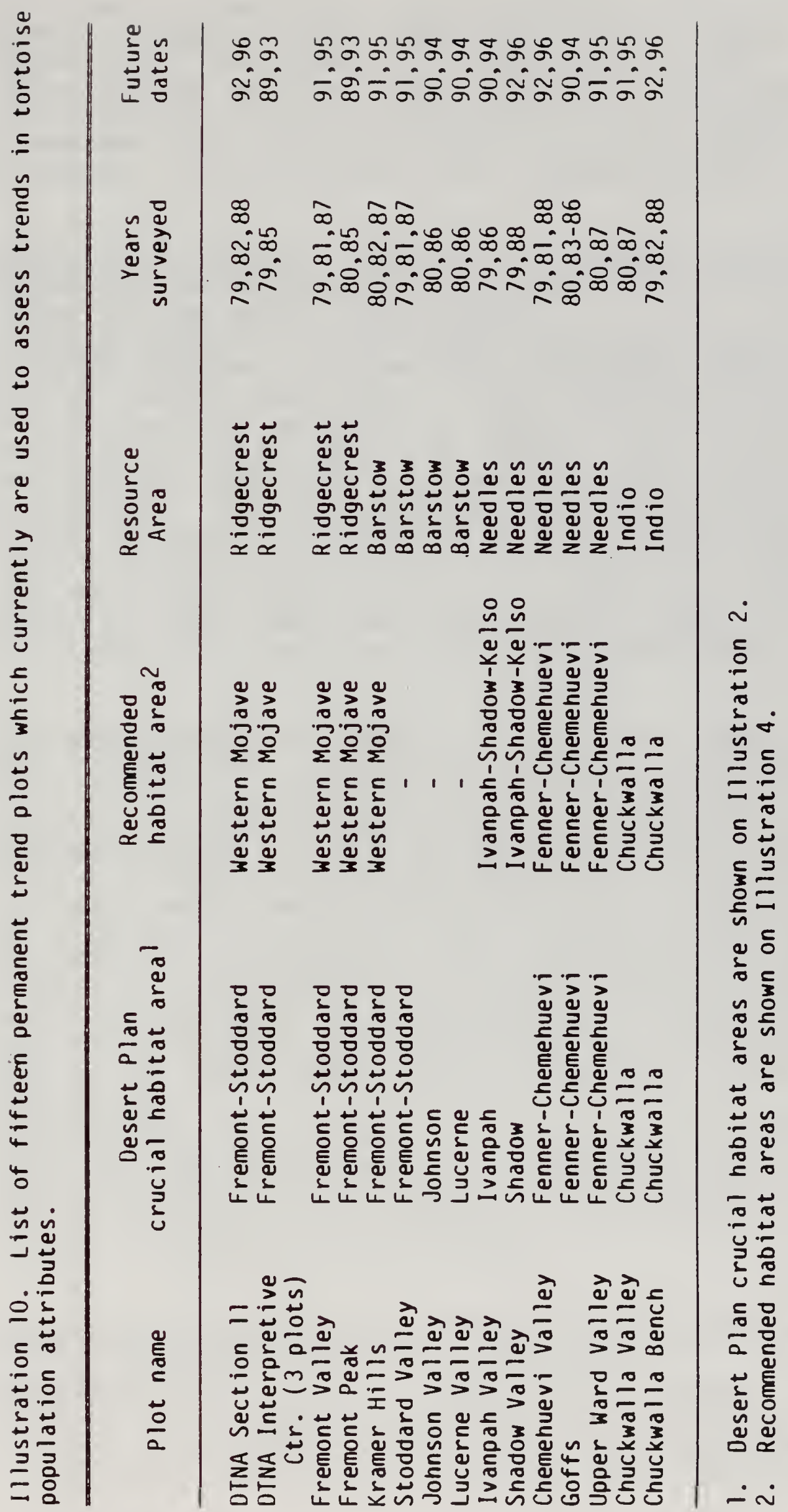


to give a reasonable time interval with an affordable yearly scope. Also, many of the 27 plots had small populations unsuitable for continued study. It may be advantageous to drop those permanent trend plots outside of Category 1 and 2 habitats (e.g.. Johnson. Lucerne. stoddard) and replace them with additional plots in Category 1 or 2 habitats (e.g.. Shadow valley).

Recommendation 43: Identify a secondary trend evaluation technique to include tortoise habitat in areas other than those with permanent trend plots.

Implementation: A monitoring technique should be developed to augment the few (15) permanent trend plots currently being monitored. The secondary system should allow areas of greater or lesser disturbance and lower density to be surveyed at lesser cost. Site selection and purpose should be specific for each monitoring plot.

Discussion: The square-mile study plots were generally sited in areas of moderate to high density and in relatively undisturbed areas: they are not representative and were not intended to be. Another monitoring technique of lower cost but with higher number of replicate plots would aid in a more representative evaluation.

Recommendation 44: Compile a list of mitigation measures and stipulations intended to benefit tortoises and conduct studies to determine their effectiveness. Modify or discontinue measures if found to be ineffective.

Implementation: A list of mitigation measures and stipulations should be compiled, maintained, and distributed: existing environmental documentation should be searched to generate the initial list. Measures which have been applied in a systematic way can be examined for effectiveness. Such studies and tests should be paid for by project proponents as new projects are permitted. Studies and tests should be distributed to other agencies and offices 80 that application of measures can be modified accordingly.

Discussion: It is important to know which measures are effective and which are not. Continued use of ineffective measures constitutes an unceasonable burden on project proponents and leads to misconceptions about the cumulative impacts on tortoises.

Recommendation 45: Require compliance reports on projects utilizing tortoise mitigation measures.

Implementation: Brief compliance reports should be required of project proponents at completion of the project. The report should indicate procedures followed in applying the measure. problems with implementation of 


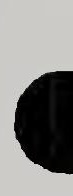

,

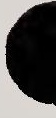


the mitigation measure, cost, and results. Interim or progress reports may be required if time to project completion is long.

Discussion: Compliance reports will indicate whether measures are actually applied effectively.

Recommendation 46: Establish study and research test plots to address special problems and to evaluate management effectiveness.

Implementation: Various sites should be identified as study plots to assess the effectiveness of the management program. Where judged necessary, additional exclosures or facilities for study of tortoises should be constructed. Exclosures will provide opportunities for future analyses that are unforeseen at this time.

Discussion: There are currently 27 trend study plots identified. Fifteen of these plots have been identified for permanent study (see Recommendation 41). In addition, an exclosure of 2.5 square miles was constructed in Ivanpah Valley in 1980 and a one-square mile fenced exclosure was constructed near Kramer Junction in 1982. Baseline vegetation surveys have been conducted at both exclosures. Various studies have also been conducted at the Desert Tortoise Research Natural Area: the Natural Area is useable for non-consumptive, non-manipulative types of studies. The Department of Fish and Game manages two parcels of one-square mile each in Fremont Valley and near Kramer Junction. The parcel near Kramer is fenced and can be used to compare to adjacent. unfenced areas. Lands currently withdrawn for the Cuddeback Dry Lake Gunnery Range may be available when the withdrawal is relinquished: there is a 4.4-square mile exclosure around the base headquarters. Conflicts and issues that might be investigated using these plots include effects from sheep grazing. cattle grazing, and ORV use.

Recommendation 47: Track habitat acquisitions and habitat losses.

Implementation: In each Bureau Resource Area office and Department field and regional office, maps should be maintained which record habitat degrading activities. Geographic information systems should be used to maintain the maps.

Discussion: It is important to begin to accurately measure the decline in useable habitat. 
Adams, J. A.. A. S. Endo, L. H. Stolzy, P. G. Rowlands, and H. B. Johnson. 1982a. Controlled experiments on soil compaction produced by off-road vehicles on the Mojave Desert. California. J.Appl. Ecol. 19:167-175.

Adams. J. A.. L. H. Stolzy. A. S. Endo, P. G. Rowlands, and H. B. Johnson. 1982b. Desert soil compaction reduces annual plant cover. Calif. Agri. 36:6-7.

Barcett, S. L., and J. A. Humphrey. 1986. Agonistic interactions between Gopherus agassizii (Testudinidae) and Heloderma suspectum (Helodermatidae). Southwest. Natur. 31:261-263.

Berry. K. H. 1974. Desert tortoise relocation project: status report of 1972. Div. Highways, state of California. Bishop. Contr. F-9353, sec. III, C. 3.

Berry. K. H. 1978. Livestock grazing and the desert tortoise. No. Am. Wildl. Nat. Resources Conf. 43:050-519.

Berry. K. H. (editor). 1984. The status of the desert tortoise (Gopherus aqassizii) in the United states. Desert Tortoise council Rept. to U. S. Fish and Wild. Serv. on Purchase Order No. 11310-0083-81. 838pp.

Berry. K. H. 1984a. Attributes of populations at twenty-seven sites in California. Chap. 5. In K. H. Berry (Ed.). The status of the desert tortoise (Gopherus agassizii) in the United States. Desert Tortoise Council Rept. to U. S. Fish and Wildl. Serv. on Purchase Order No. 11310-0083-81.

Berry. K. H. 1984b. A description and comparison of field methods used in studying and censusing desert tortoises. App. 2. In K. H. Berry (Ed.). The status of the desert tortoise (Gopherus agassizii) in the United states. Desert Tortoise Council Rept. to U. S. Fish and Wildl. Serv. on Purchase Order No. 11310-0083-81.

Berry. K. H. 1984c. Human activities in desert tortoise crucial habitats in California. Chap. 6. In K. H. Berry (Ed.). The status of the desert tortoise (Gopherus agassizii) in the United states. Desert Tortoise Council Rept. to U. S. Fish and Wildl. Serv. on Purchase Order No. 11310-0083-81.

Berry, K. H. 1984d. The distribution and abundance of desert tortoises in California from the 1920's to the 1960's and a comparison with the current situation. chap. 4. In K. H. Berry (Ed.). The status of the desert tortoise 
(Gopherus agassizii) in the United states. Desert Tortoise council Rept. to U. S. Fish and Wildl. Serv. on Purchase Order No. 11310-0083-81.

Berry. K. H. 1985. Avian predation on the desert tortoise (Gopherus agassizii) in California. Rept. to so. Calif. Edison Co.. Rosemead. California.

Berry. K.H. 1986a. Desert tortoise (Gopherus agassizii) relocation: implications of social behavior and movements. Herpetologica 42:113-125.

Bercy. K. H. $1986 \mathrm{~b}$. Incidence of gunshot deaths in desert tortoise populations in California. Wildl. Soc. Bull. 14:127-132.

Berry. K. H, and L. L. Nicholson. 1984a. The distribution and density of desert tortoise populations in California in the 1970's. Chap. 2. In K. H. Berry (Ed.). The status of the desert tortoise (Gopherus agassizii) in the United states. Desert Tortoise Council Rept. to U. S. Fish and wildl. Serv. on Purchase order No. 11310-0083-81.

Berry. K. H, and L. L. Nicholson. 1984b. A summary of human activities and their impacts on desert tortoise populations in California. Chap. 3. In K. H. Berry (Ed.). The status of the desert tortoise (Gopherus agassizii) in the United states. Desert Tortoise Council Rept. to U. S. Fish and Wildl. Serv. on Purchase order No. 11310-0083-81.

Berry, K. H, L. L. Nicholson, S. Juarez, and A. P. Woodman. 1986. Changes in desert tortoise populaions at four study sites in Califoria. U. S. Bureau of Land Manage.. Calif. Desert Dist.. Riverside California.

Berry. K. H.. T. Shields, A. P. Woodman. T. Campbell. $\mathrm{J}$. Roberson. K. Bohuski, and A. Karl. 1986. Changes in desert tortoise populations at the Desert Tortoise Research Natural Area between 1979 and 1985 . U. S. Bureau of Land Manage.. Calif. Desert Dist.. Riverside. California.

Berry, K. H. and F. B. Turner. 1984. Activity patterns. behavior. and habitat preferences of juvenile desert tortoises (Gopherus agassizii) in California. Proc. Desert Tortoise Council Symp. 1984:111-130.

Bour, R. and A. Dubois. 1984. Xerobates agassiz. 1857. synonym plus ancien de Scaptochelys Bramble. 1982 (Reptilia. Chelonii. Testinidae). Extr. Bull. Mensuel soc. Linneenne Lyon $53(1): 30-32$. 
Bramble, D. 1971. Functional morphology, evolution and paleoecology of gopher tortoises. Unpubl. Ph.D. Dissertation. Univ. of California, Berkeley.

Bramble. D. 1982. Scaptochelys: generic revision and evolution of gopher tortoises. Copeia 1982(4):852-867.

Bramble. D. 1986. Keynote Address. Paper presented at the 1986 Symp. of the Desert Tortoise Council. Palmale. California.

Bury. R. B. 1978. Desert tortoises and ORVs: do they mix? Proc. Desert Tortoise Council Symp. 1978:126.

Bury, R. B..R. A. Luckenbach, and S. D. Busack. 1977. Effects of off-road vehicles on vertebrates in the california desert. U.S. Fish and Wildlife serv.. Wildife Res. Rept. No. 8 .

Busack, S. D.. and R. B. Bury. 1974. Some effects of off-road vehicles and sheep grazing on lizard populations in the Mojave Desert. Biol. Conserv. 6:179-183.

California Department of Fish and Game. Manual on fish and wildife mitigation and compensation.

Campbel1. T. 1982. Hunting and other activities on and near the Desert Tortoise Natural Area, eastern Kern County. California. Proc. Desert Tortoise Council symp. $1982: 90-98$.

Campbel1. T. 1983. Some natural history observations of desert tortoises and other species on and near the Desert Tortoise Natural Area. Kern County. California. Proc. Desert Tortoise Council symp. 1982:80-88.

Coffeen. M. 1984. State Report - Utah. Proc. Desert Tortoise Council symp. 1984:30-31.

Cooper. J. E.. and O.F. Jackson (Eds.). 1981. Diseases of the Reptilia. Volumes 1 and 2. Academic Press.

Diamond. J. 1975. The island dilemma: lessons of modern biogeographic studies for the design of natural reserves. Biol. Conserv. 7:129-146.

Diamond. J. 1976. Island biogeography and conservation: strategy and limitations. Science 193:1027-1029.

Foreman. L. D.. J. M. Brode, R. Haussler, and K. Kramer.

1986. The responsibilities of federal and state agencies for protection of the desert tortoise in california. Herpetologica $49: 59-62$. 
Frankel. O. H.. and M. E. Soule. 1981. Conservation and evolution. Cambridge University Press. Great Britain.

Fusari. M. 1981. Feasibility of a highway crossing system for desert tortoises. Report to California Department of Transportation. Sacramento. California.

Haley. R. 1986. Tortoise management in Nevada - 1985. Paper presented at the Ann. Meeting and Symp. of th Desert Tortoise coun. March 1986. Palmdale. California.

Hoff. G. L.. F. L. Frye, and E. R. Jacobson (Eds.) 1984.

Diseases of amphibians and reptiles. Plenum Press. New York and London.

Jarchow. J. 1987. Report on investigation of desert tortoise mortality on the Beaver Dam Slope. Arizona and Utah. Rept. for Arizona Game and Fish Dept.. Bureau of Land Mgmt. in Arizona and Utah, and Utah Div. of Wildife Resources.

Lamb. T. 1986. Genetic variation in mitochondrial DNA of the desert tortoise. Gopherus agassizii. in California: a preliminary report. Paper presented at the Ann. Meeting and symp. of the Desert Tortoise Coun. March 1986. Palmale. California.

Lamb. T. 1987. Poster presented at the Ann. Meeting and Symp. of the Desert Tortoise Coun. March 1987. Las Vegas. Nevada.

Lamb. T.. J. C. Avise, and J. W. Gibbons. In press.

Phylogeographic patterns in mitochondrial DNA of the desert tortoise (Xerobates agassizi) with emphasis on evolutionary relationships among North American gopher tortoises. Evolution.

Luckenbach. R. A. 1982. Ecology and management of the desert tortoise (Gopherus agassizii) in California. Pp. 1-37. In R. B. Bury (Ed.). North American Tortoises: Conservation and Ecology. U.S. Fish and Wildfl. Serv.. Wildl. Res. Rept. 12.

Mack. R. N. 1983. Invaders at home on the range. Nat. Hist. Mag. $93: 40-47$.

Marlow. R.. and K. Tollestrup. 1982. Mining and exploitation of natural mineral deposits by the desert tortoise. Gopherus agassizii. Anim. Behav. 30:475-478.

Medica, P. A.. R. B. Bury, and R. A. Luckenbach. 1980 . Drinking and construction of water catchments by the desert tortoise. Gopherus agassizii. in the Mojave Desert. Herpetologica 36:301-304. 

Medica, P. A., C. L. Lyons, and F. B. Turner. 1982. A comparison of 1981 populations of desert tortoises. Gopherus agassizii. in grazed and ungrazed areas in Ivanpah Valley. California. Proc. Desert Tortoise Council symp. 1982:99-124.

Mortimer. C. 1984. State Report - Nevada. Proc. Desert Tortoise Council symp. 1984:17-23.

Mortimer. C. and P. Schneider. 1983. Population studies of the desert tortoise (Gopherus agassizii) in the Piute Valley study plot of southern Nevada. Nevada Dept. of Wildlife. Las Vegas. Draft Rept.

Nicholson. L. L. 1978a. The effects of roads on desert tortoise populations. Rept. to U. S. Bureau of Land Management, Riverside, Calif.

Nicholson. L. L. 1978b. The effects of roads on desert tortoise populations. Proc. Desert Tortoise Council symp. 1982:127-129.

Nicholson. L.. and K. Humphreys. 1981. Sheep grazing at the Kramer study plot. San Bernardino County. California. Proc. Desert Tortoise Council Symp. 1981:163-194.

Patterson. R. 1971. Vocalization in the desert tortoise. Gopherus agassizi. M. A. Thesis. California state College. Fullerton.

Patterson. R. 1976. The distribution of the desert tortoise. Proc. Desert Tortoise Council Symp. 1976:14-21.

Patterson. R. 1982. The distribution of the desert tortoise (Gopherus agassizii). Pp. 5l-55. In R. B. Bury (Ed.). North American Tortoises: Conservation and Ecology. U. S. Fish and Wild. Serv.. Wildl. Res. Rept. 12.

Roberson. J.. B. L. Burge, and P. Hayden. 1985. Nesting observations of free-living desert tortoises (Gopherus agassizii) and hatching success of eggs protected from predators. Proc. Desert Tortoise Council symp. 1985 :

St. Amant. J. 1984. California state regulations for wild and captive tortoises. Chapter 7. In K. H. Berry (Ed.). The status of the desert tortoise (Gopherus agassizii) in the United states. Desert Tortoise Council Rept. to U. S. Fish and Wildl. Serv. on Purchase Order No. 11310-0083-81.

Sheridan. D. 1981. Desertification of the United States. Council on Environmental Quality. Supt. Documents. U.S. Gov. Print. Off.. Washington. D. C. 
Soule. M. E. 1986. Conservation Biology: The science of scarcity and diversity. Sinauer Associates. Inc.. Massachusetts.

Soule. M. E. and B. A. Wilcox (Eds.). 1980. Conservation Biology: an evolutionary-ecological perspective. Sinauer Associates. Inc.. Massachusetts.

stebbins. R. C. 1985. A Field Guide to Western Reptiles and Amphibians. Houghton Mifflin Co.. Boston.

stockton, L. 1984. The Desert Tortoise Natural Area: A review of successes and failures. Appendix 8 . In $K$. $H$. Berry (Ed.). The status of the desert tortoise (Gopherus agassizii) in the United States. Desert Tortoise Council Rept. to U. S. Fish and Wildl. Serv. on Purchase order No. $11310-0083-81$.

Turner, F. B.. and K. H. Berry. 1984a. Methods used in analyzing desert tortoise populations. App. 3 . In K. $\mathbf{H}$. Berry (Ed.). The status of the desert tortoise (Gopherus agassizii) in the United states. Desert Tortoise Council Rept. to U. S. Fish and Wildl. Serv. on Purchase Order No. 11310-0083-81.

Turner, F. B.. and K. H. Berry. 1984b. Population ecology of the desert tortoise at Goffs, California. Southern Calif. Edison. Co. Res. and Dev. Ser. 84 RD-4. Rosemead. Calif.

Turner. F. B.. and K. H. Berry. 1985. Population ecology of the desert tortoise at Goff8. California in 1984. Southern California Edison. Co. Ann. Rept. 85 RD-63. Rosemead. Calif.

Turner, F. B.. and K. H. Berry. 1986. Population ecology of the desert tortoise at Goff8. California in 1985. Univ. Calif.. Los Angeles. No. 12-1544.

Turner, F. B.. and K. H. Berry, D. C. Randall, and G. C. White. 1987. Population ecology of the desert tortoise at Goff8. 1983-1986. Rept. to southern California Edison Co.. Rosemead. Calif.

Turner, F. B.. P. Hayden, B. L. Burge, and J. B. Roberson. 1986. Egg production by the desert tortoise (Gopherus agassizii) in California. Herpetologica 42:93-104.

Turner, F. B., P. A. Medica, C. L. Lyons. 1981. A comparison of

populations of desert tortoise. Gopherus agassizii in grazed and ungrazed areas in Ivanpah Valley. California. Proc. Desert Tortoise Council Symp. 1981:139-162. 

Turner, F. B.. P. A. Medica, C. L. Lyons. 1984. Reproduction and survival of the desert tortoise (scaptochelys agassizi) in Ivanpah Valley. California. Copeia 1984:811-820.

U. S. Bureau of Land Management. 1973. Interim critical management plan for recreational venicle use on the California desert. U. S. Bur. Land Manage.. Calif. Desert Program. Riverside. $87 \mathrm{pp}$.

U. S. Bureau of Land Management. 1974. BLM reports on conditions of western rangelands. Bureau of Land Management News Release, Sept. 3, 1974. Washington, D. C.

U. S. Bureau of Land Management. 1980. The California Desert Conservation Area Plan. U. S. Bur. Land Manage.. Calif. Desert District, Riverside. $173 \mathrm{pp}$.

U. S. Bureau of Land Management. 1986. Draft Management Plan for the Desert Tortoise Natural Area and Area of Critical Environmental Concern (A Sikes Act Plan). U. S. Bur. Land Manage.. Ridgecrest Resource Area. Ridgecrest. Calif.

U. S. Fish and Wildlife Service. 1985. Endangered and threatened wildife and plants: finding on desert tortoise petition. Fed. Reg. 50:49868-49870.

Uptain. C. 1987. Human activities and their associated impacts on and adjacent to the Desert Tortoise Natural Area, Kern County. California. Rept. for Californa Dept. of Fish and Game, Rancho Cordova. California.

Uptain. C.. and A. E. Karl. 1987. Desert tortoise surveys for the Luz Solar Generating Facility. Kramer Junction. San Bernardino County. California. Rept. submitted to Luz Engineering Corporation and ERT Company.

Vale. T. R. 1975. Report by Bureau of Land Management on range conditions and grazing in Nevada. Biol. Conserv. 8-257-260.

Voigt. W.. Jr. 1976. Public grazing lands: use and misuse by government and industry. Rutgers Univ. Press. New Jersey.

Webb, R. H.. and S. S. Stielstra. 1979. Sheep grazing effects on Mojave Desert vegetation and soils. Envir. Mgmt. $3: 517-529$.

Weber. A.. J. C. Cook, and G. R. Stewart. 1979. A second report on survival in rehabilitated desert tortoises. Proc. of Desert Tortoise Council Symp. 1979:101-103. 
Weinstein. M. and K. Berry. 1988. Morphometric analysis of desert tortoise populations. U. S. Bureau of Land Management, Riverside CA Contr. No. CA-950-CT7-003.

Weinstein. M. K. H. Berry, and F. B. Turner. 1987. An analysis of habitat relationships of the desert tortoise in California. Rept. to southern Calif. Edison Co.. Rosemead. California.

Whitcomb, R. F., J.F. Lynch, and P.A. Opler. 1976. Island biogeography and conservation:

strategy and limitations. Science 193:1030-1032. 
( 
Rec. no. Recommendation subject

Page

Establish a tortoise coordinating committee

Encourage other agencies to implement recommendations

the Department

41 Transfer desert portion of Kern county to Region 5 



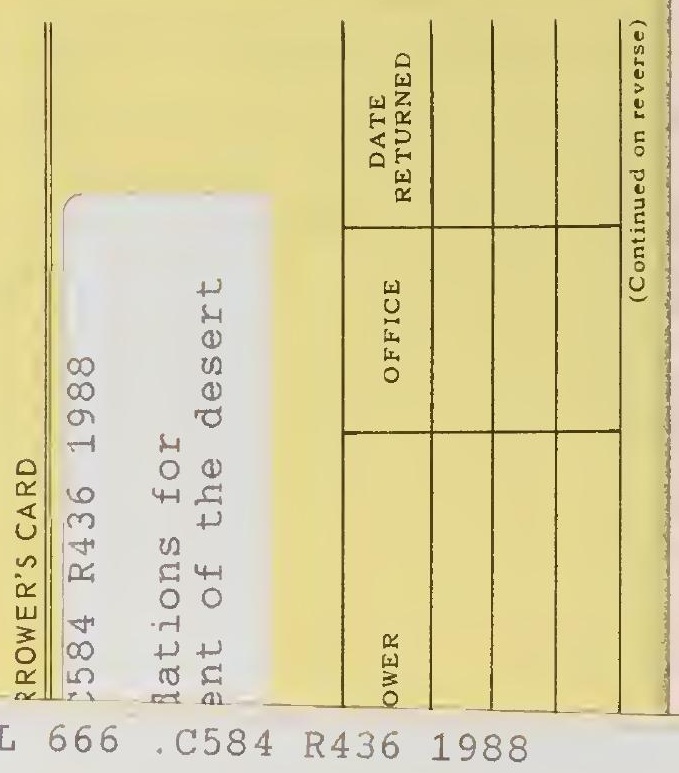

Recommendations for management of the desert

\section{BLMLIBRARY}

PS 150A BLDG. 50

DENVER FEDERAL CENTEP

P.O. BOX 25047

DENVER, CO 80225 


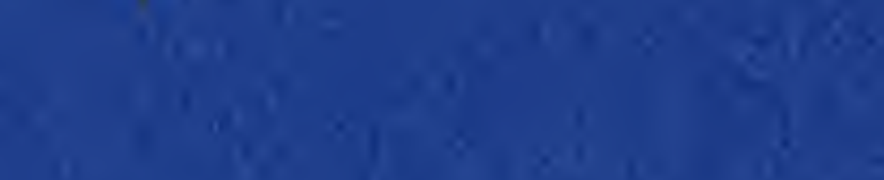

$$
\begin{aligned}
& \text { (18) }
\end{aligned}
$$

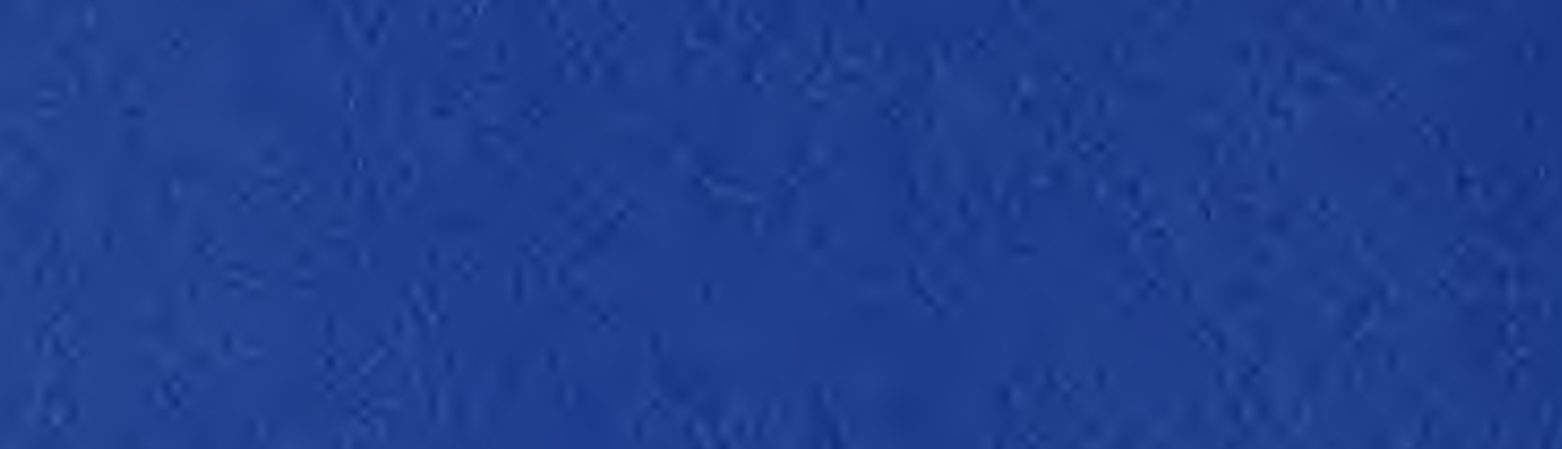
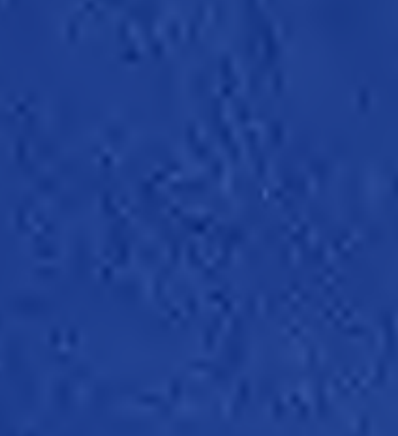

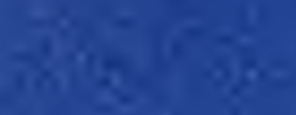

W.

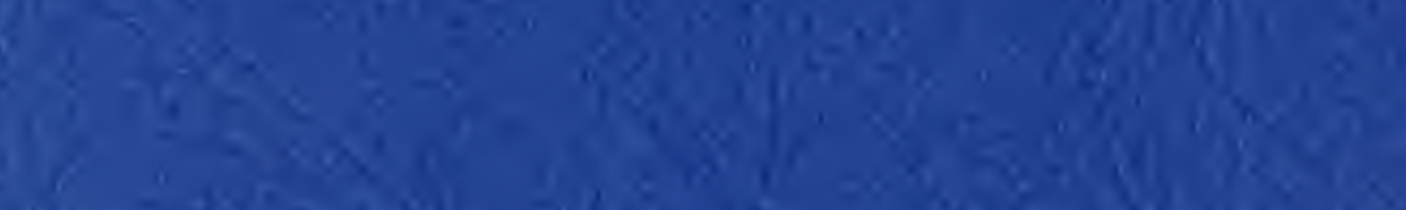

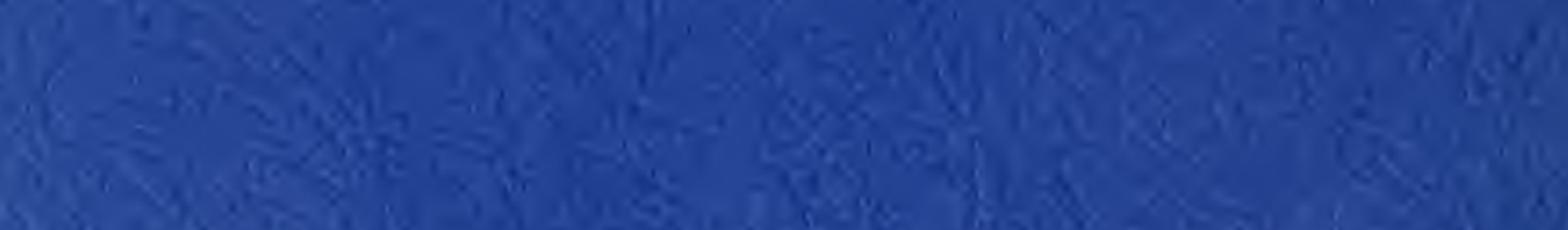

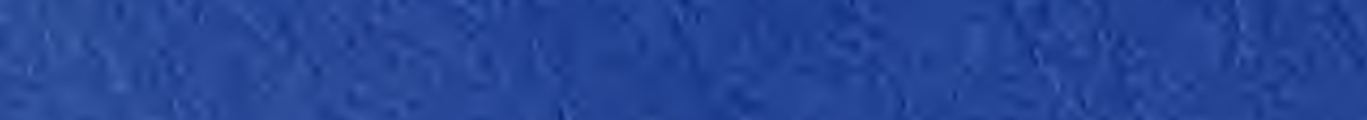

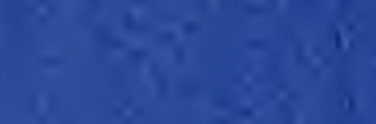
$\frac{5}{4}, x_{1}^{2}-1$

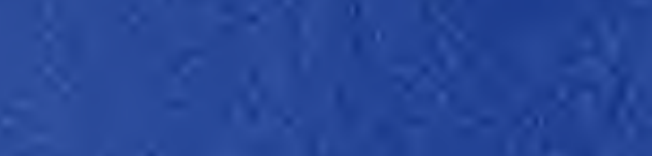

$-\sin 2 x$

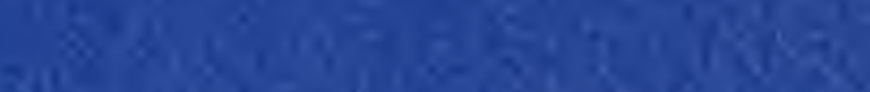

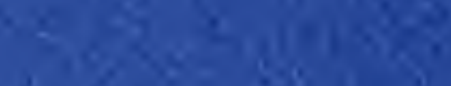

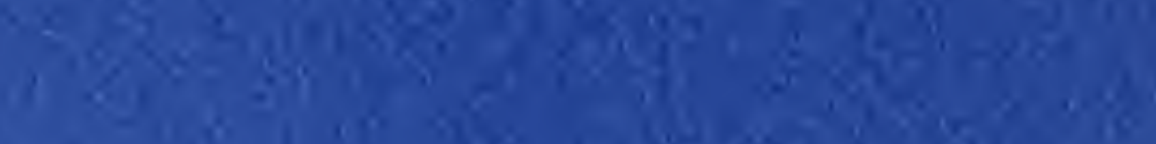
aitsolivite c) $f(x) 1\}$

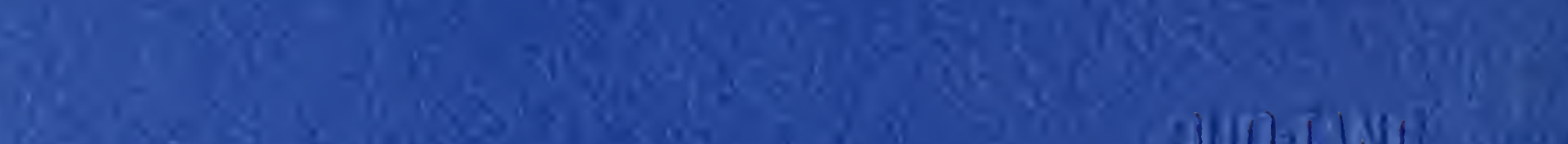

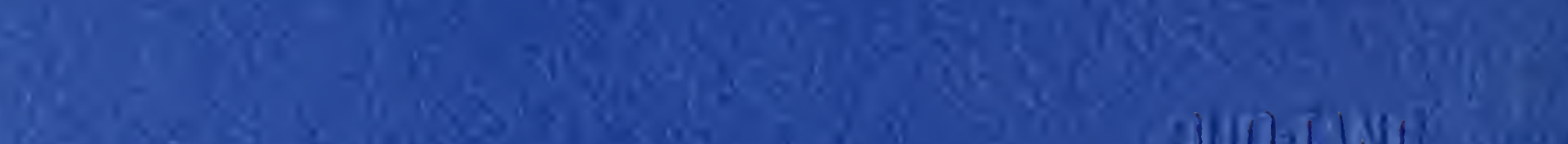

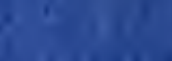

-

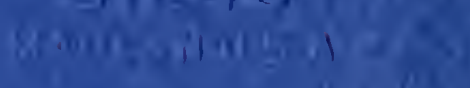

